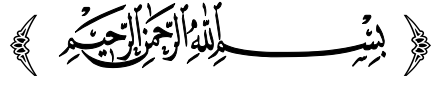

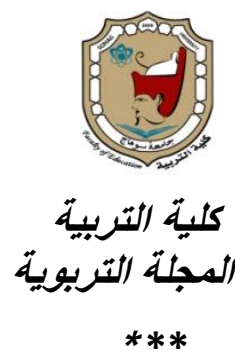

درجة استفدام الإدارة الإلكتزونية وعلاقتها بالإبداع الإداري للدى

قادة المدارس بمحافظة العقيق

$$
\text { | - (إعداد }
$$

أ أ فائز بن هميّل فائز الدعجاني

باحث ماجستير في القيادة التريوية

المجلة التزبوية.العدد السابع والخمسوز ـ يناير 19+rم

Print:(ISSN 1687-2649) Online:(ISSN 2536-9091) 
ملخص:

هافت الدراسة إلى الكشف عن درجة استخدام الإدارة الإكترونية وعلاقتها بالإبداع الإداري لاى قادة المدارس بمحافظة العقيق، وذلك من وجهة نظر كل من المعلمين وقادة المدارس، ولتحقيق أهداف الدراسة تم اتباع المنهج الوصفي بصورته المسحية، كما تم اختيار عينة طبقية عشوائية من المعلمين بلغ عددها ا YY، أما عينة القادة فقد تم استخدام

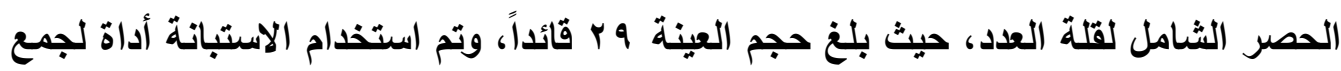
البيانات، وذلك بعد التحقق من صدقها وثباتها، حيث أظهرت النتائج أن تقدير أفراد عينة

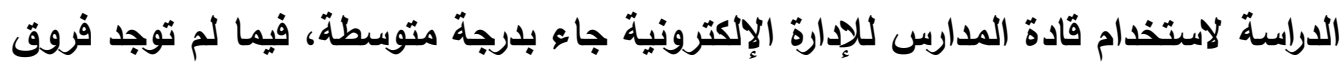
ذات دلالة إحصائية عند مستوى 0.05 < في الارجة الكلية وأبعاد المحور الأول (استخدام الإدارة الإلكترونية)، تعزى لجميع متغيرات الدراسة؛ أما بالنسبة للمحور الثاني (الإبداع الإداري

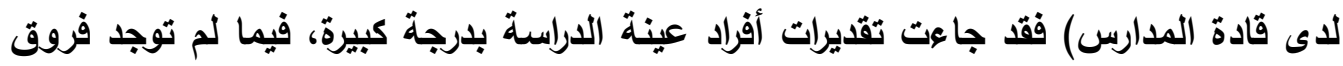
ذات دلالة إحصائية عند مستوى الدلالة 0.05 > في الارجة الكلية وأبعاد هذا المحور تعزى لمتغيرات: سنوات الخبرة، المرحلة التعليمية، المؤهل العلمي، التخصص، فيما وجدت فروق دالة إحصائياً عند مستوى الدلالة 0.05 م وفقاً لمتغير نوع العمل لصالح قادة المدارس وذلك في الارجة الكلية وثلاثة أبعاد للإبداع الإداري (الأصالة، المرونة، الحساسية 
درجة استخدام الإدارة الإككتونية وعلاقتها بالإبداع الإداري لدى قادة المدارس بمحافظة العقيق

The study aimed to identify The degree of use of electronic management and its relationship to administrative creativity among school leaders in Al-Aqeeq Governorate, from the teachers and school leaders 'point of view, and to achieve objectives of the study were followed descriptive approach with survey image. A random sample of 221 teachers, as for the sample of leaders, a comprehensive inventory was used for the small number; then the sample size was 29 leaders. The questionnaire was used as a data collection tool after verifying their validity and validity. The study found that the total score of the sample of the study sample of the teachers and leaders of the general education schools in Al-Aqiq governorate for the use of the leaders of the schools for e-management was (intermediate). There were no statistically significant differences at the level of significance $\alpha \leq 0.05$ the first axis use of electronic administration, due to all its variables, also the total score for the assessment of the sample members of the study for administrative creativity was large, while there were no statistically significant differences at the level of significance $\alpha \leq 0.05$ in the total score and the dimensions of the second axis (administrative innovation), due to the variables (years of experience, educational stage, scientific qualification, specialization). There were statistically significant differences at the significance level $\alpha \leq 0.05$ According to the variable of the type of work for the leaders of schools in the overall degree and three dimensions of the dimensions of the second axis, while the variable type of work for the leaders of schools in the overall degree and three dimensions of administrative innovation (originality, flexibility, sensitivity to problems). 


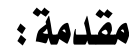

مع التدفق الكبير للمطلومات في جميع المجالات، ويفضل تطور وسائل الاتصال، أصبح تجدد المعلومة هو السمة المميزة لهذا العصر، حيث تحول هذا العالم الواسع إلى قرية إلكترونية صغيرة. فعالم اليوم يدار عن طريق شبكات منتظمة ويسرعة فائقة وذلك بعد ظهور الإنترنت واستخدامه في كافة مجالات العمل ومناحي الحياة المختلفة.

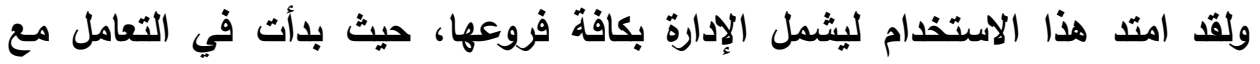

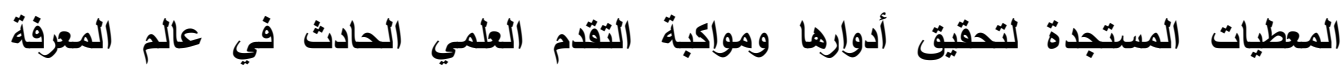
والاتصال، والإدارة المدرسية كغيرها من الإدارات الأخرى، تأثرت بهذه التطورات وعملت على فلى فئل

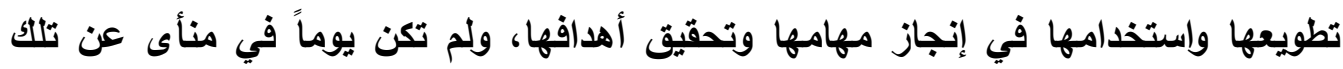

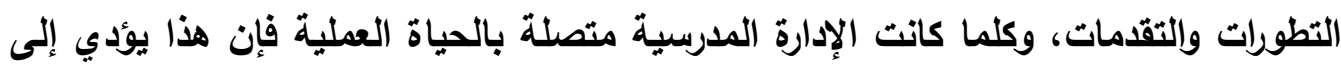

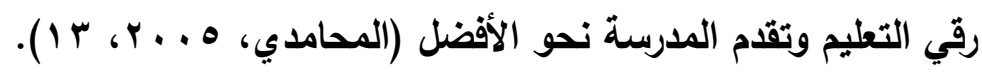
غير أن الإدارة الدرسية أصبحت تواجه تحديات التغيير والتطوير المستمر، ومن أبرز

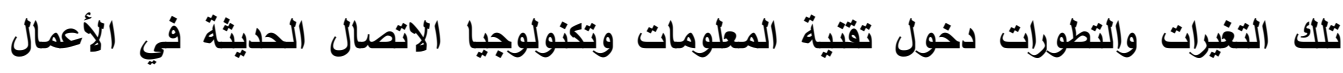

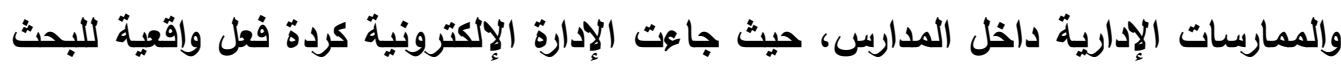

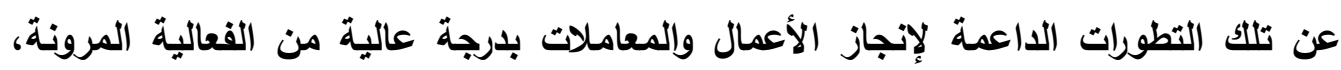

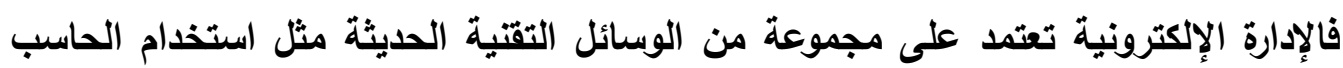

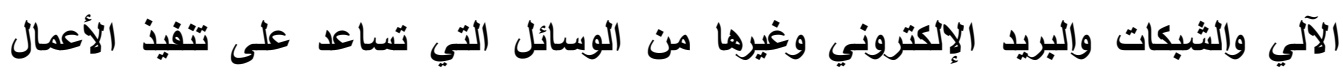

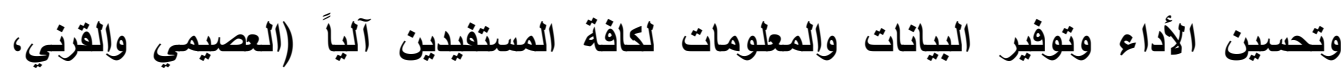

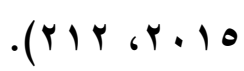

كما تعمل الإدارة الإكترونية على تحقيق مجموعة من الأهداف عند تطبيقها في مجال التعليم، حيث تقلل من التعقيدات الإدارية، وتحسن مستوى الذذمات المقدمة للعملاء، كما

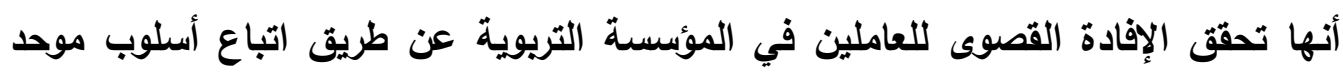

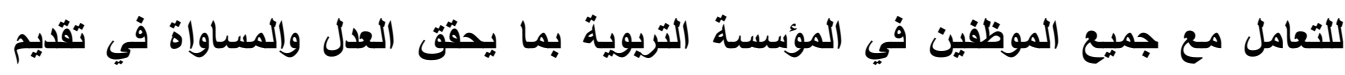

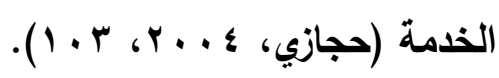
ووفقاً لهذه المزيا فإن الإدارة الإلكترونية تتميز بأنها إحدى الأدوات التي تساعد على

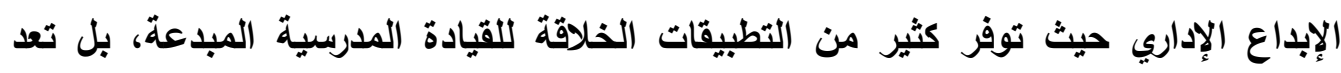


مطلباً ضرورياً للقيام بدورها بكفاءة، وهو ما يدعو إليه الفكر الإداري المعاصر، حيث يؤكد

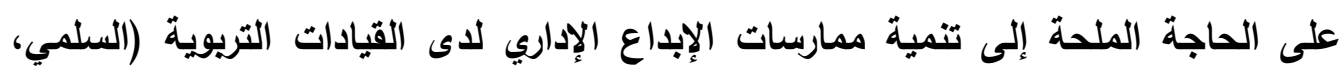

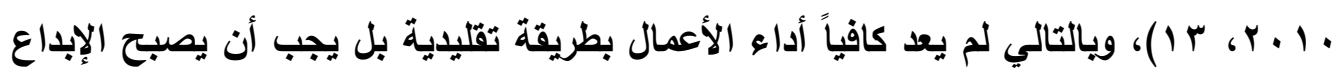

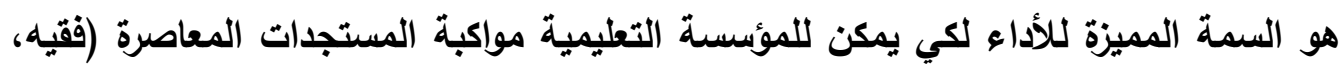
.(^) 6 . . . .

مما سبق يتضح الدور الذي تؤديه الإدارة الإكترونية ومدى مساهمتها في مساعدة

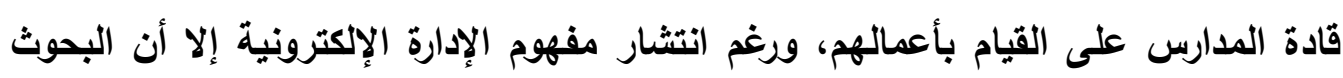

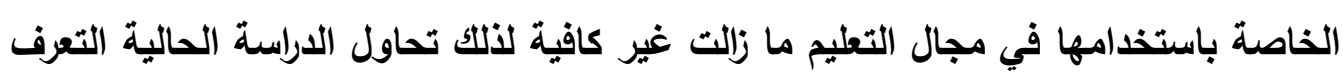

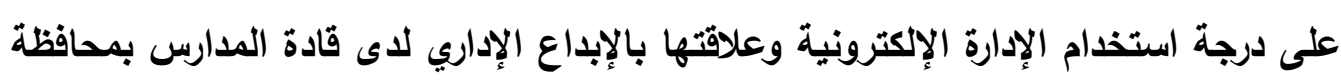
العقيق.

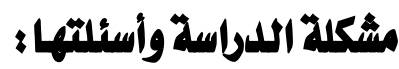

تتجه كثير من المؤسسات التعليمية في عالمنا المعاصر إلى تطبيق الإدارة الإكترونية،

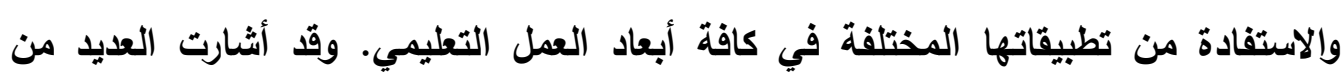

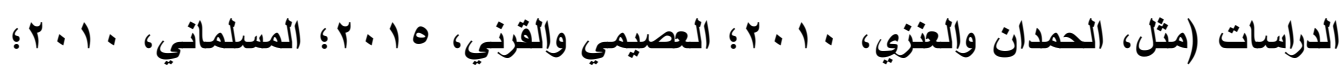

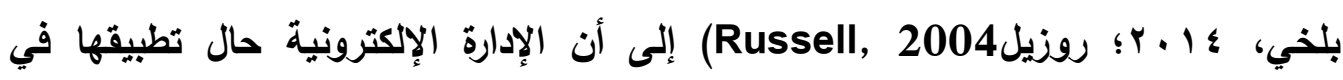
المدارس سوف تساعد قادة المدارس على القيام بالأعمال الملقاة على عاتقهم بكل يسر الإلى

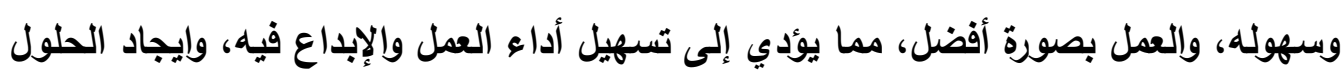

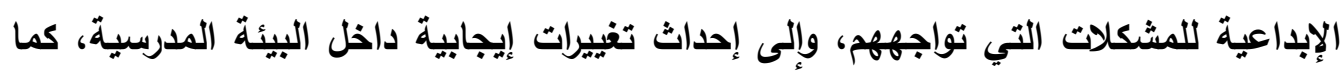
تساعدهم على التكيف مع المتغيرات البيئية المحيطة كافة والتفاعل معها، والارتقاء بمستوى إلته أداء العاملين فيها، وايجاد مقترحات وأفكار عمل مباعة وخلاّة. وعلى الرغم من انتشار مفهوم الإدارة الإلكترونية في مختلف مجالات العمل وفي وفي جميع المؤسسات إلا إن العديد من الدراسات التي تم إجراءها (مثل: المرعي، 10

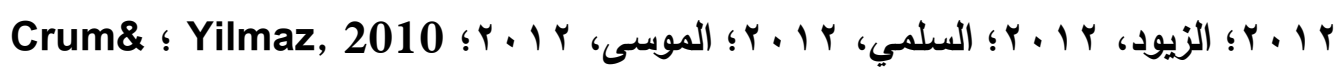

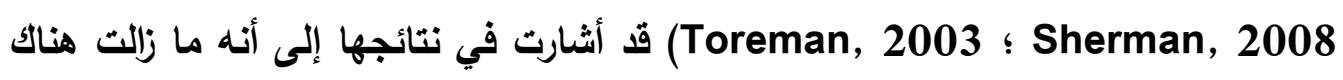
فجوة في تحقيق التوافق مع التغيرات التكنولوجية والاجتماعية والثقافية المؤئرة سواءً على ماتى 
مستوى البيئة القريبة أو البعيدة للمدرسة، كما أثشارت إلى وجود العديد من جواتب القصور المتعلقة بضعف قرة الإدارة المدرسية على مسايرة المبادئ والأساليب الإدارية الحديثة. وعلى الرغم من الاعتراف المتزايد بأهمية تنمية الإبداع في جميع النواحي الإدارية بالمدارس، إلا أنه لا تزال هناك فجوة في تحقيق التوافق مع التغيرات التقتية والاجتماعية

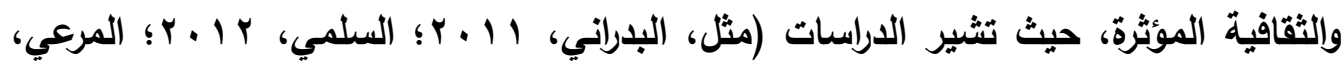

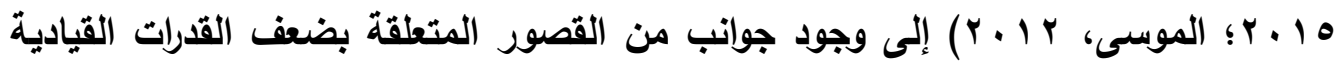
الإبداعية لاى قادة المدارس، وعدم المقدرة على مسايرة ومواكبة الأساليب الإدارية الحديثة. لذا تتلخص مشكلة الاراسة في الإجابة عن السؤال الرئيس: ما العلاقة بين استخدام الإدارة الإكترونية والإبداع الإداري لاى قادة المدارس بمحافظة العقيق؟ الإبه وقد تفرع من هذا السؤال الرئيس الأسئلة الفرعية الآتية: ا. ما درجة استخدام قادة المدارس بمحافظة العقيق للإدارة الإكترونية من وجهة نظر قادة الكة ومعلمي المدارس؟ r. هل توجد فروق ذات دلالة إحصائية عند مستوى الدلالة 0.05 > في درجة تقدير أفراد عينة الدراسة لدرجة استخدام الإدارة الإكترونية لاى قادة المدارس بمحافظة العقيق تعزى إلى متغيرات الدراسة (طبيعة العمل، سنوات الخبرة، المرحلة التعليمية، المؤهل العلمي، (التخصص) r. ما درجة الإبداع الإداري لدى قادة المدارس بمحافظة العقيق من وجهة نظر قادة ومعلمي

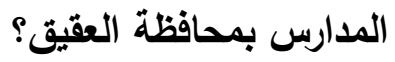
ع. هل توجد فروق ذات دلاله احصائية عند مستوى الالالة 0.05 > في درجة تقدير أفراد عينة الدراسة لارجة الإبداع الإداري لاى قادة المدارس في محافظة العقيق تعزى لمتغيرات الاراسة (طبيعة العمل، سنوات الخبرة، المرحلة التعليمية، المؤهل العلمي، التخصص) هـ هل توجد علاقة ارتباطية دالة بين درجة استخدام الإدارة الإكترونية ودرجة الإبداع الإداري

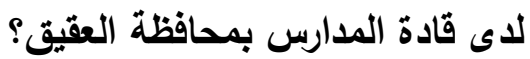




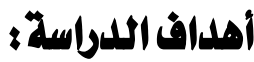

هدفت الدراسة إلى التعرف على درجة استخدام قادة المدارس بمحافظة العقيق للإدارة

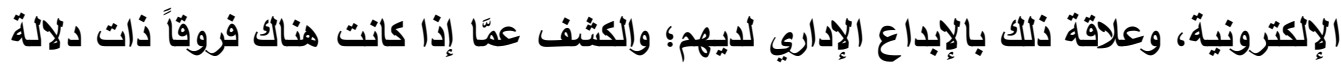
إحصائية بين استجابات أفراد العينة حول درجة استخدام الإدارة الإلكترونية والإبداع الإداري يمكن أن تعود إلى متغيرات الدراسة (طبيعة العمل، سنوات الخبرة، المرحلة التعليمية، المؤهل العلمي، التخصص).

\section{أهمية اللداسلة:}

أولاً: الأهمية النظرية.

يؤمل من هذه الدراسة أن تقدم إضافة في الأدب النظري لواقع استخدام الإدارة

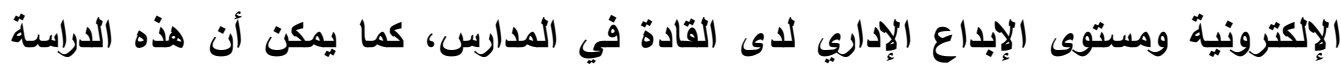

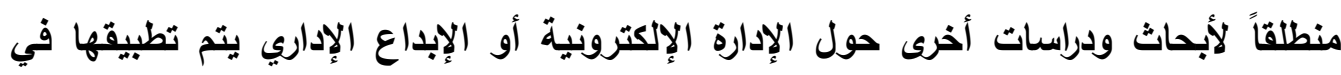
محافظات أخرى بالمملكة بما توفره من أدب نظري ودراسات سابقة ذات صلة أو من خلال الإدات الاراسات المقترحة التي سوف تقدمها. ثانياً: الأهمية التطبيقية. يُؤمل أن يستفيد من نتائج هذه الدراسة قادة المدارس في محافظة العقيق من خلال تعرفهم مواطن الضعف ونقاط القوة فيما يتطلق باستخدامهم للإدارة الإكترونية في مدارسهر

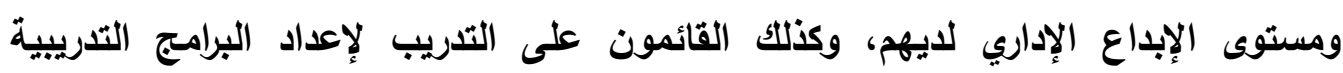
المناسبة لقادة المدارس في مجالي الإبداع الإداري والإدارة الإلكترونية.

\section{الأدب النظري المتفيرات الدراسلة:}

تناولت الدراسة الحالية متغيرين رئيسين، يمكن التأصيل لهما على النحو التالي:

الإدارة الإكترونية Electronic Management

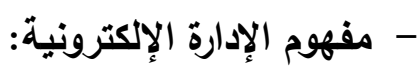

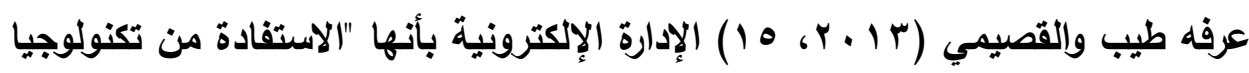

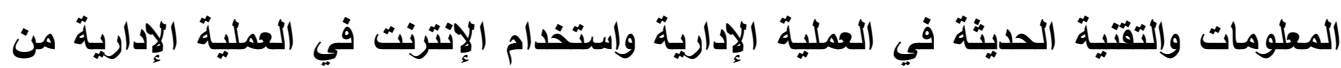

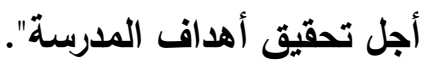


كما تعرف بأنها استخام الأساليب الإلكترونية (الحاسب الآلي والانترنت) في تحسين سير العملية الإدارية داخل الددرسة وتسهيل الاتصالات ومشاركة المعلومات بين المدرسة وغيرها من المؤسسات المرتبطة بها (Turner \& Weickgenannt, 2009, 15). ويتفق الباحث مع آراء الكتاب والباحثين حول مفهوم الإدارة الإلكترونية بأنها استخدام وتسخير لكافة الإمكانيات التقتية الحديثة والمتاحة وتوظيفها والاستفادة منها في العمل

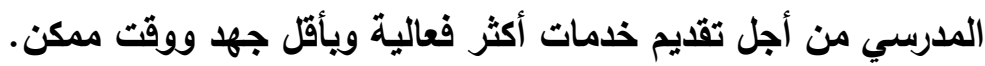
- أهمية الإدارة الإكترونية وأهدافها: تُعد الإدارة الإلكترونية عصب حياة المجتمعات المدنية الحديثة التي كانت مسيرة حياتها اليومية تواجه أزمات خانقة في ظل إداراتها التقليدية حتى استطاعت أن تخطو خطوات لافتئة من أجل تجاوز هذه الأزمات بفعل التكنولوجيا. وينظر إلى الإدارة الإكترونية على أنها بديل عصري يواكب التطور الذي حدث في حياة الإنسان على سطح الأرض، ويلبي مطالبه الإدارية، ويرضي طموحه في الحصول على قرات أعلى وأيسر في إدارة شؤون حياته

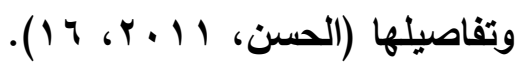
ومما سبق تتضح أهمية تطبيق الإدارة الإكترونية في المؤسسات التريوية فهي تدخل في جميع المجالات الخاصة بهذه المؤسسات بقوة لتقايم المساعدة على الانجاز بأفضل التهل وأسرع وأدق ما يمكن. - مجالات تطبيق الإدارة الإكترونية في المدارس:

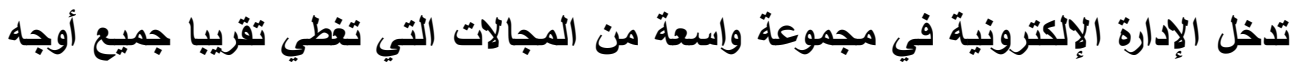
النشاط داخل المدارس والمؤسسات التعليمية، ومنها ما يلي: I. مجال إدارة شؤون الطلاب: يُقصد بشؤون الطلاب كل ما له علاقة بالطلاب وما يخص الهص

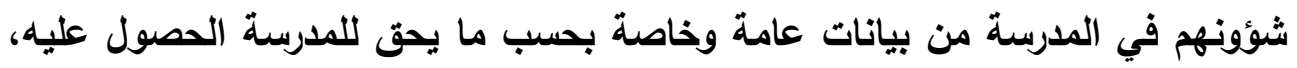

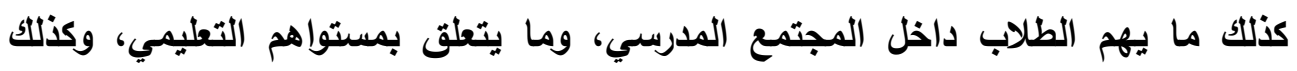

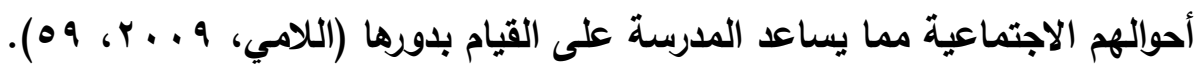

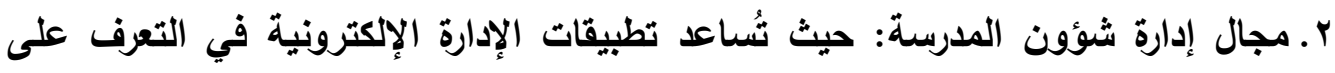
الاحتياجات المدرسة، كما تساعد في تقدير الاحتياجات المستقبلية نتيجة لما توفره من العنات احصائيات ومعلومات حول جميع المكونات والعناصر المتعلقة بالمدرسة، ويُمكن أن تقام تلات 
الإدارة الإلكترونية مجموعة من الخدمات منها: خدمات الاتصالات، والتي يكون هدفها ريط

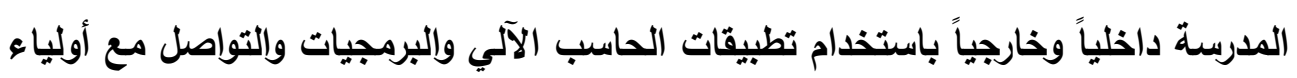

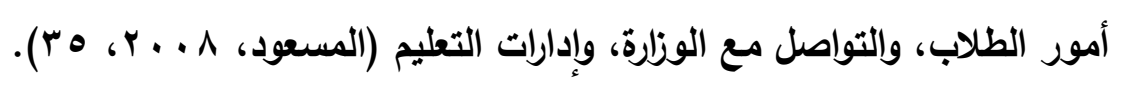

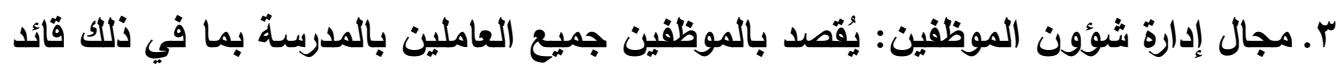

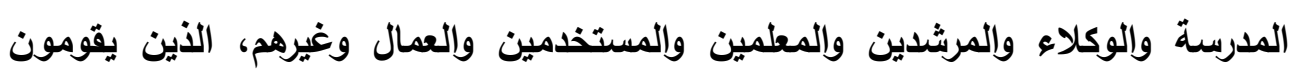

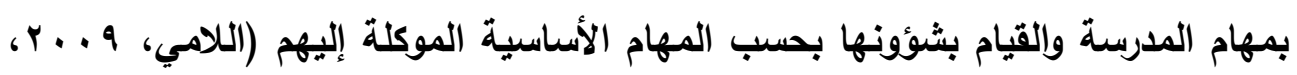
.$(\circ \mathrm{V}$

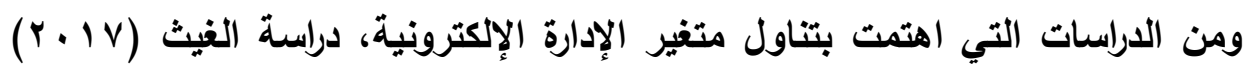

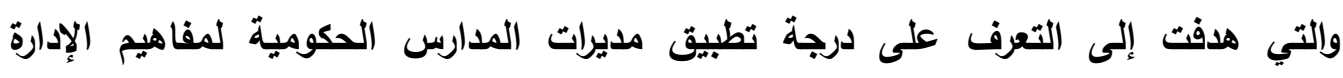

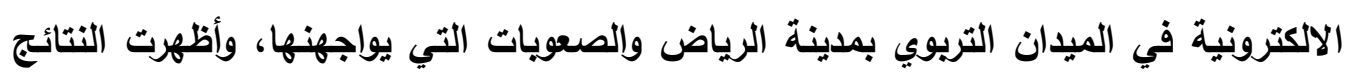

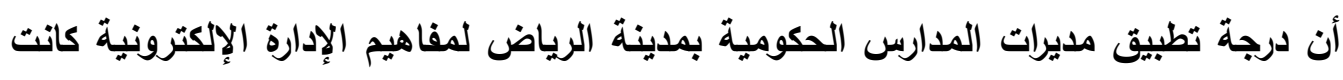

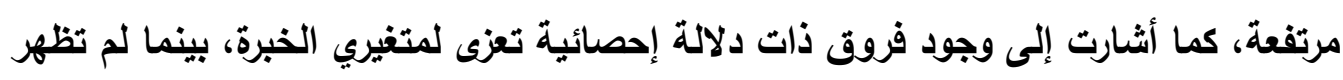

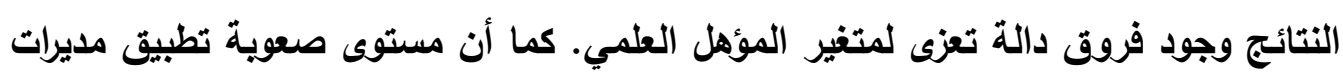

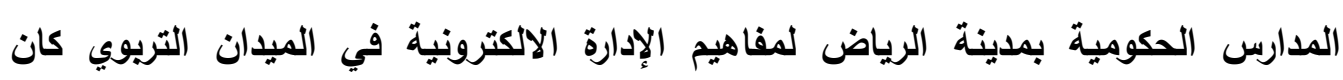
منخفضاً.

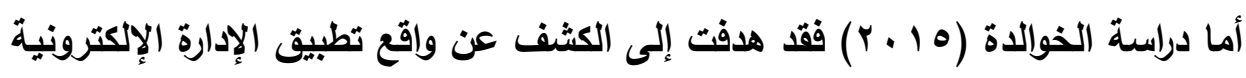

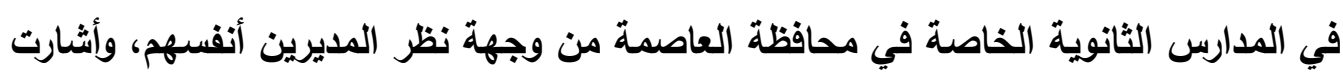

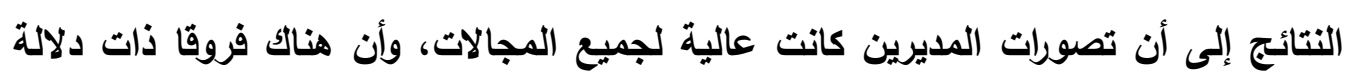

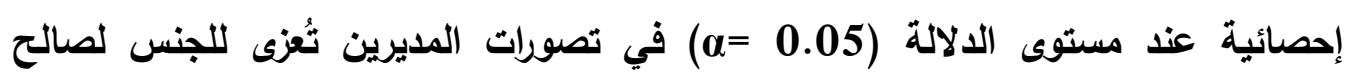

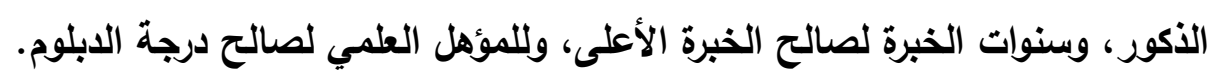

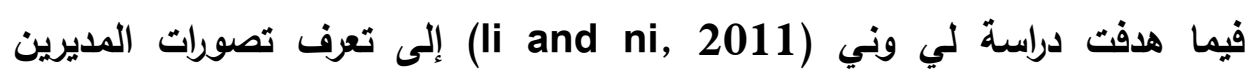

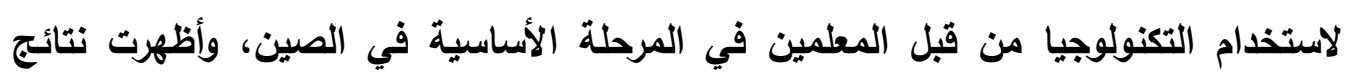

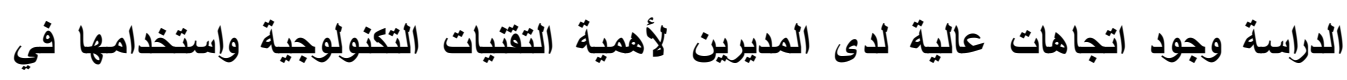

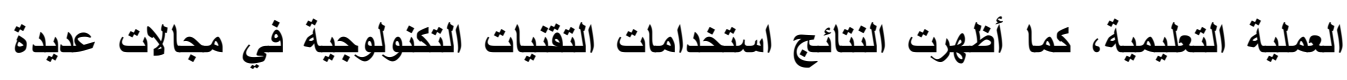
منها: التخطيط التعليمي، وأساليب التدريس الصفي، وتنمية التفكير لاى الطلبة. الإبداع الإداري Administrative Creativity 


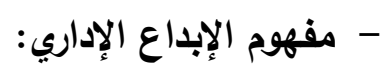

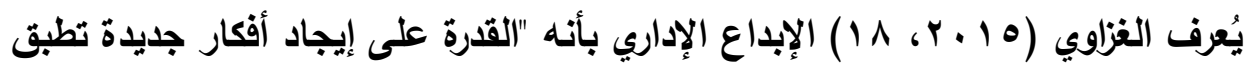
في عمليات الإدارة من تخطيط وتنظيم وتوجيه ورقابة وتقويم للوصول إلى ميزة تنافسية بين الإدارات المدرسية، واستخدام حول ابتكارية للمشكلات التي تواجه المؤسسة التريوية".

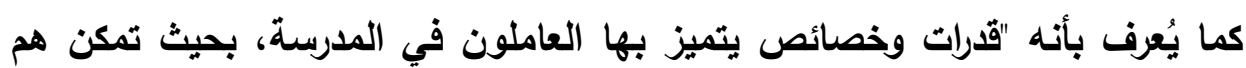
من إنتاج فكرة جديدة متميزة قابلة للتطبيق، بهدف حل مشكلة أو تطوير نظام قائم لتتفيذ

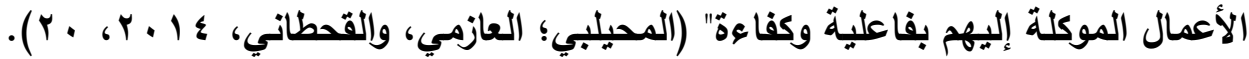
ومن مراجعة التعريفات السابقة يمكن القول بأن هذه التعريفات يوجد بينها مجموعة العانة من الأفكار المشتركة وهي أن الإبداع الإداري يركز على وجود فكرة أو ممارسة جديدة تؤدي لئدي إلى تطوير وتقدم المؤسسة، واكتثاف طرق إبداعية ومداخل للتغيير نحو الأفضل.

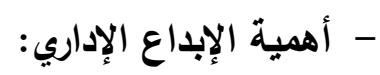
تتبع أهية الإبداع الإداري من كونه عملية مُركبة تتضمن الإحساس بوجود مشكلة تحتاج إلى حل، والقدرة على التفكير وفق متطلبات جديدة بهذف ابتكار الحل المناسب

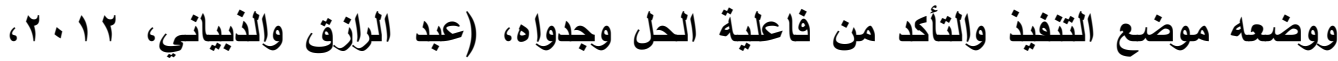
.$(194$

وتُشير الأدبيات إلى أهمية الإبداع الإداري داخل المنظمات باختلاف أنواعها، وتكمن

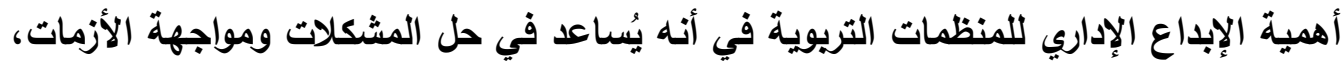

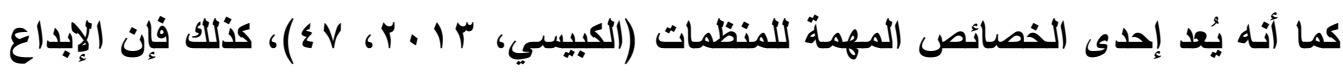

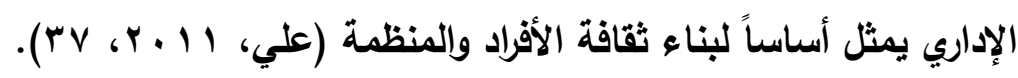

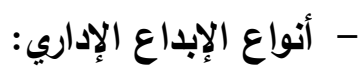
أشثارت الأدبيات التريوية إلى وجود أنواع مختلفة من الإبداع الإداري فيرى العاجز

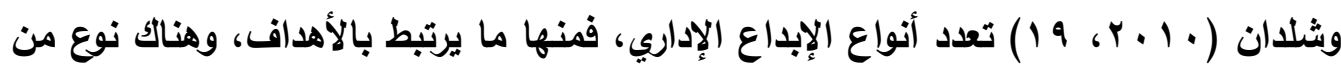

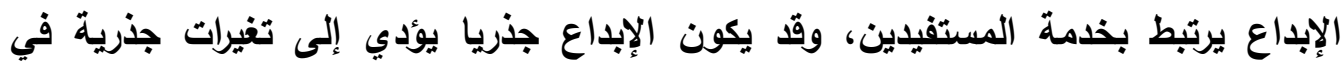
الدرسة أو قد يكون جزئيا يؤدي إلى حدوث تغيرات ثانوية. 


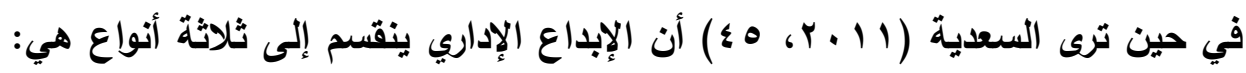

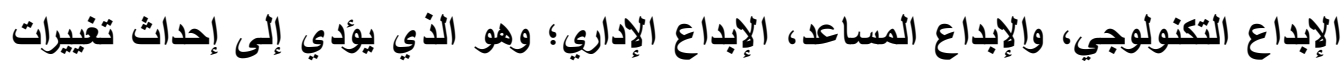

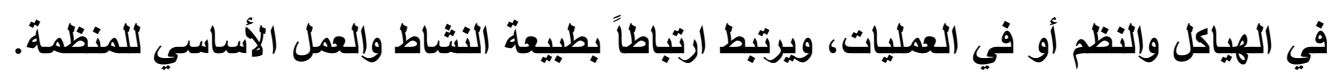
- عناصر الإبداع الإداري لاى قادة المدارس:

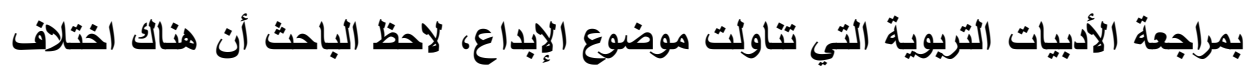

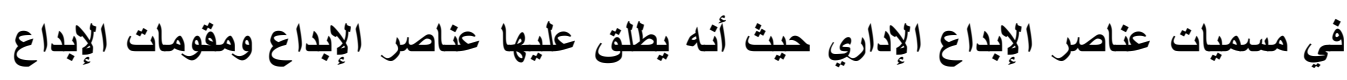

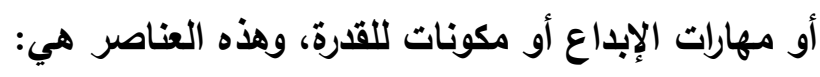

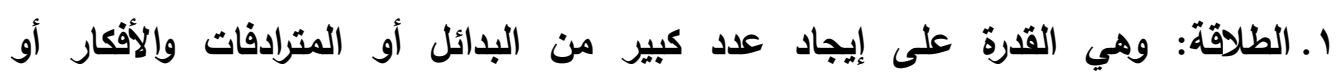

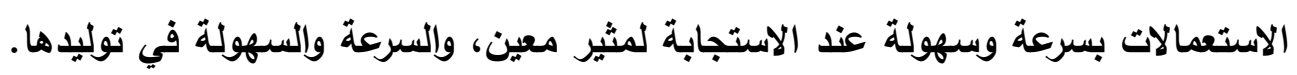

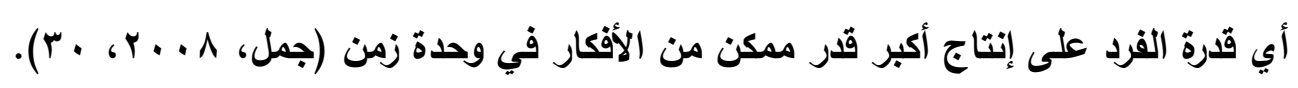

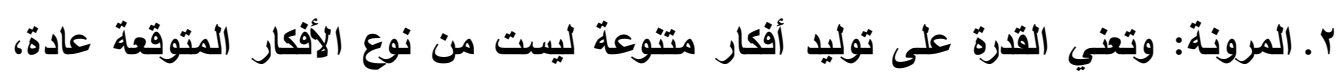

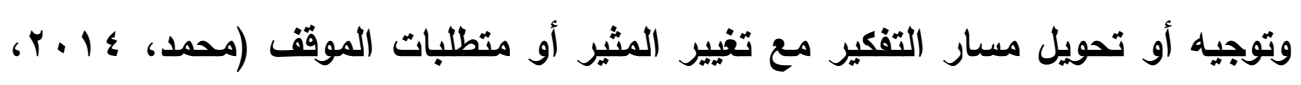

r. إدراك التفاصيل: تثمل هذه القدرة على إضافة التفاصيل لفكرة ما والتي تتضمن التطوير

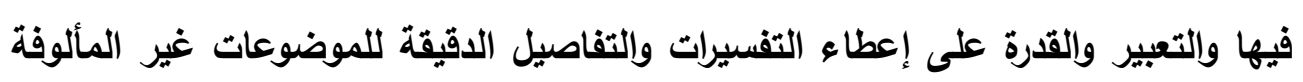

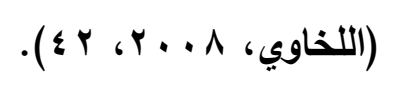

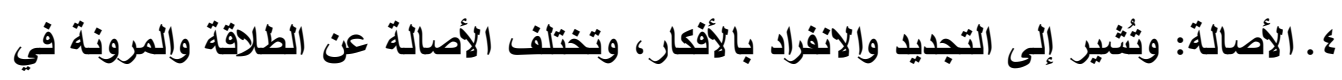

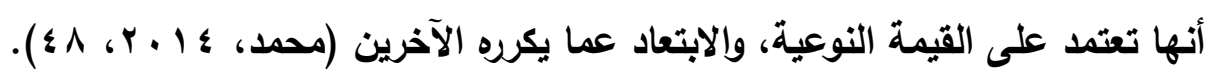

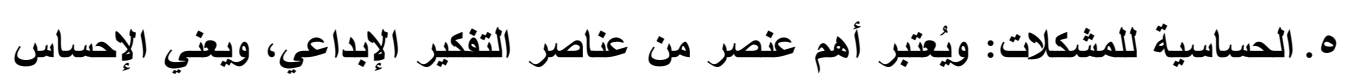

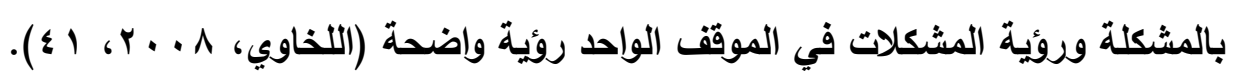

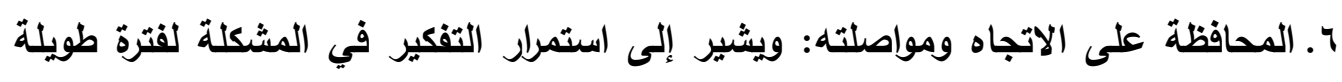

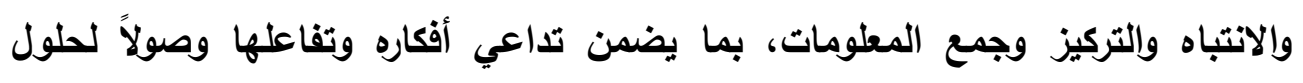

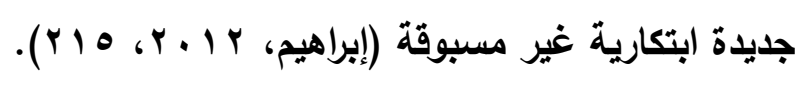

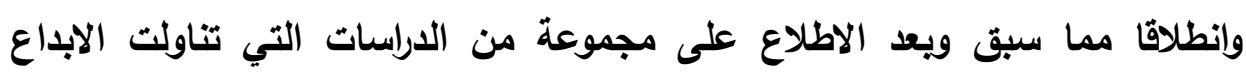

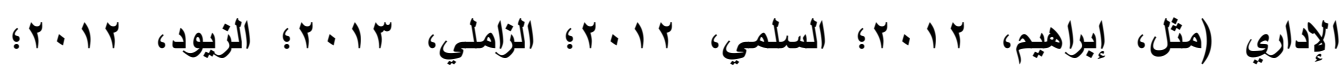

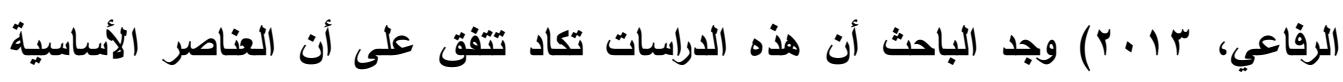


المكونة للإبداع الإداري هي (الطلاقة، المرونة، الأصالة، الحساسية للمشكلات، المحافظة

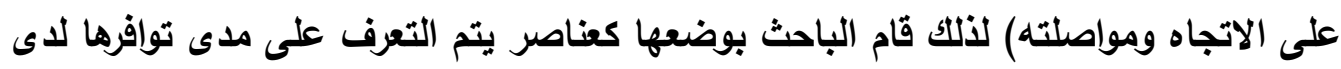
قادة الددارس بمحافظة العقيق عن طريق أداة الدراسة.

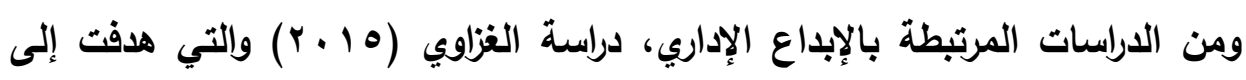

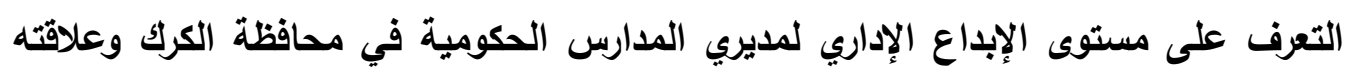

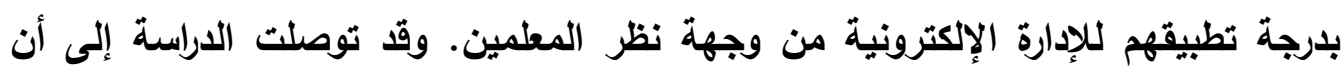

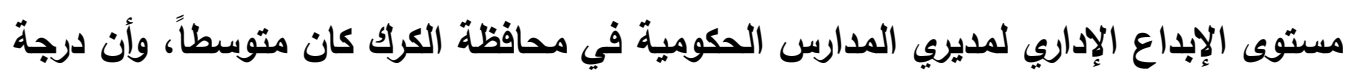

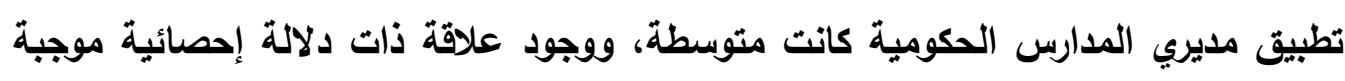

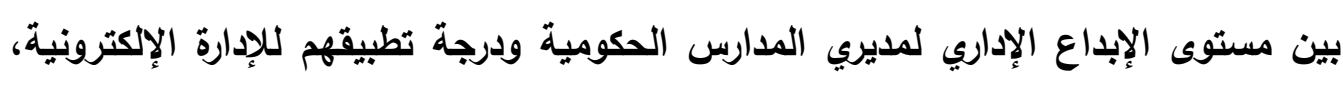

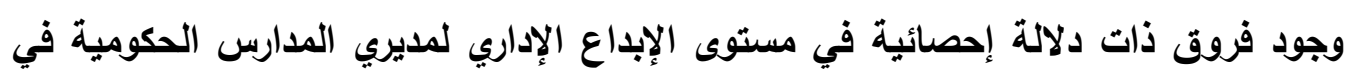

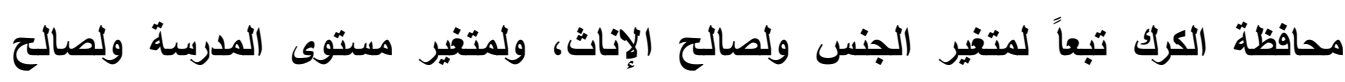

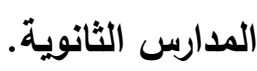

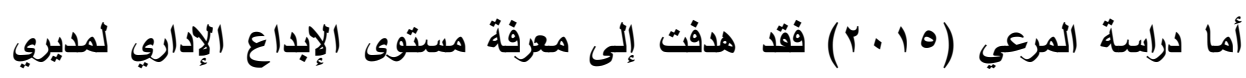

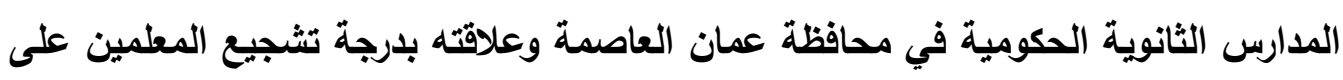

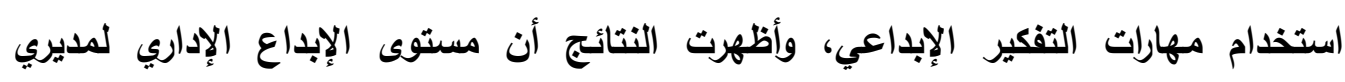

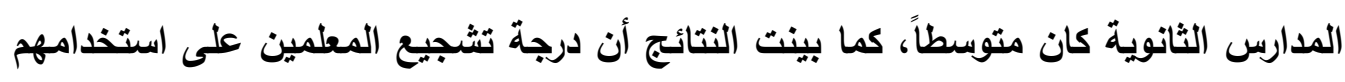

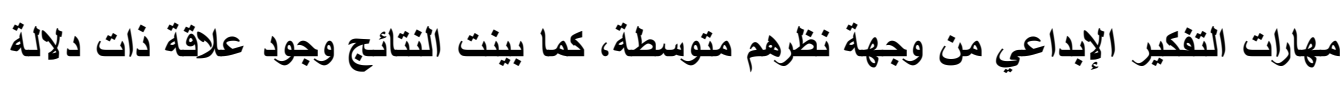

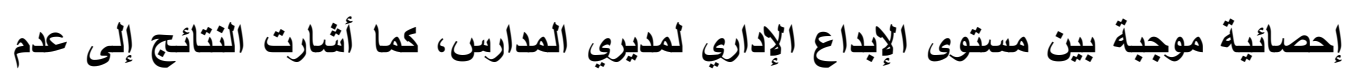

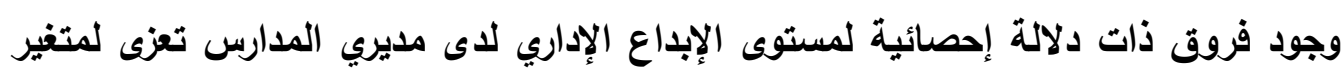
الجنس.

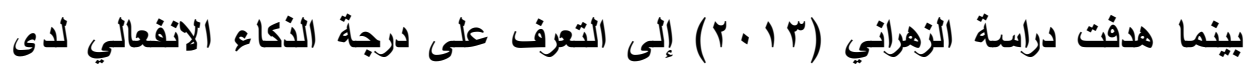

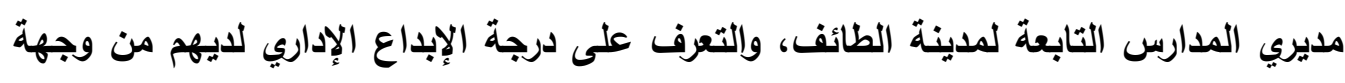

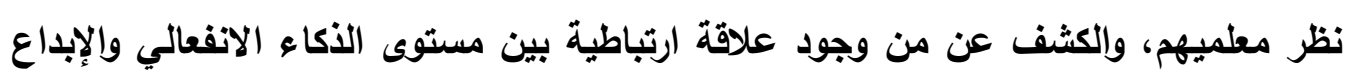

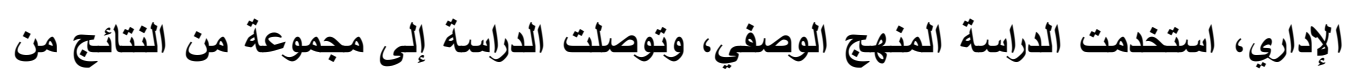

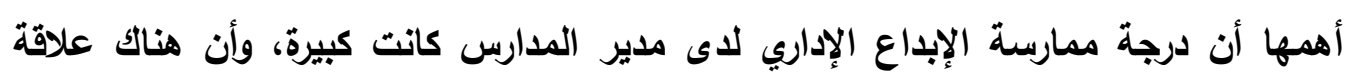
ارتباطية دالة موجبة بين مستوى الذكاء الانفعالي والإبداع الإداري. لإئ. 
في حين سعت دراسة سالفي (Salfi, 2011) إلى التعرف على ممارسات الإدارة الإبداعية الناجحة عند المديرين وأثرها في تحسين مستوى الأداء التعليمي للمطلمين

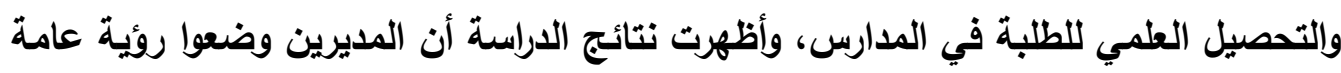

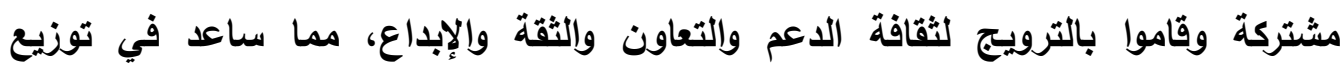
مسؤوليات الإدارة الإبداعية في جميع أنحاء المدرسة، وفي عملية صنع القزار، والعلاقات

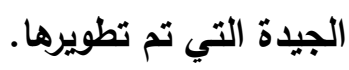

فيما هدفت دراسة كروم وشيرمان (Crum\& Sherman, 2008) إلى التعرف على فئل

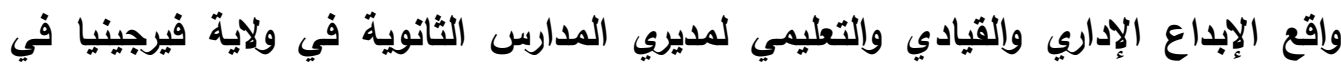
الولايات المتحدة الامريكية وأثره على تطوير أداء العاملين في المدرسة لتحقيق مستويات الإئ

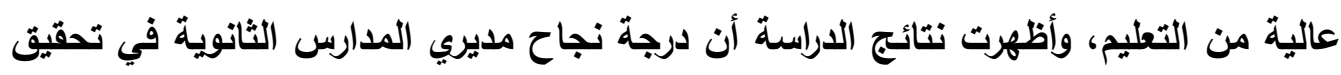
مستويات عالية عند الطلبة ارتكز على الممارسات الإدارية الإبداعية الفعلية لايهر.

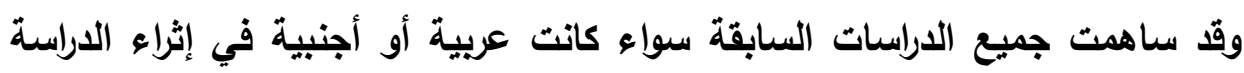

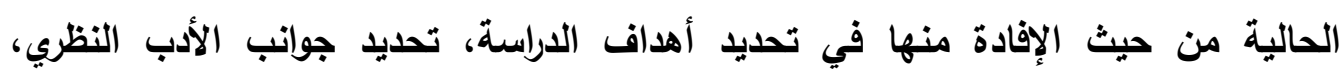
والاسترشاد بها في بناء وإعداد وتكييف أداة الداسة.

مثهجية الداساسة يتبع البحث المنهج الوصفي بصورته المسحية؛ لكونه الأنسب لطبيعة البحث وأهدافه؛ التي تتحدد في الكثف عن واقع العلاقة بين متغيراته. - مجتمع وعينة الدراسة: - مئل تكون مجتمع الدراسة من جميع قادة ومعلمي العدارس بمحافظة العقيق والبالغ عدادهم

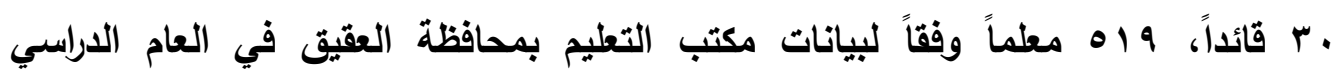

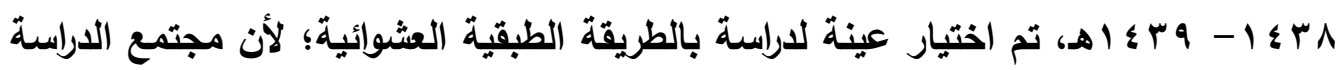

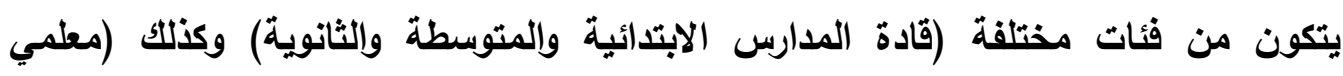

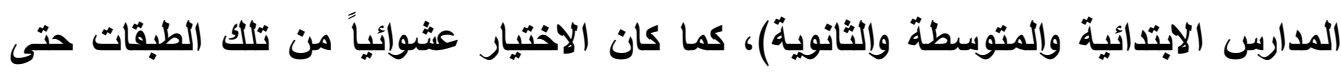

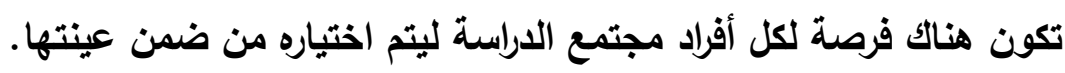

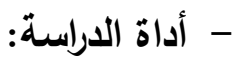


نظراً لطبيعة الاراسة فقد أستخدمت الاستبانة كأداة لجمع المعلومات والبيانات المتعلقة بهذه الدراسة، وقد مر بناء الاستبانة بالخطوات العملية التالية: 1. مراجعة الأدب النظري للاراسة والدراسات السابقة التي هدفت إلى قياس الإدارة الاكترونية

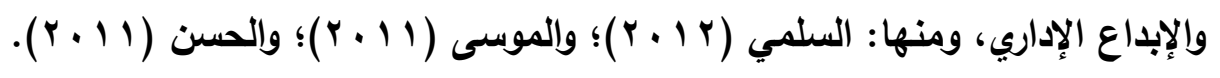

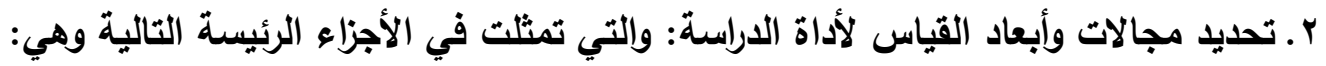
- الجزء الأول: يتضمن البيانات العامة عن المستجيبين وفق المتغيرات الديموجرافية.

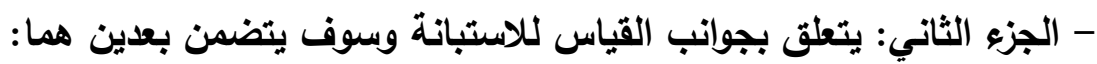
المحور الأول: ممارسة قادة مدارس محافظة العقيق للإدارة الاككترونية. المحور الثاني: ممارسة قادة مدارس محافظة العقيق للإبداع الإداري.

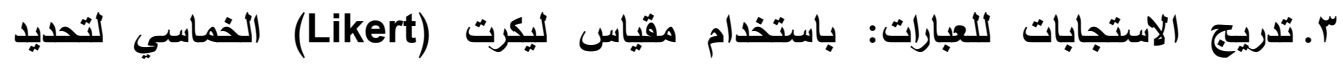
استجابات أفراد عينة الدارسة على العبارات (كبيرة جداً، كبيرة، متوسطة، قليلة، قليلة

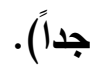

؛. حساب الخصائص السيكومترية لأداة الاراسة: وذلك عبر الخطوات الإجرائية التالية: (1) الصدق: قام الباحث بحساب صدق المقياس باستخدام طريقتين وهما كما يلي:

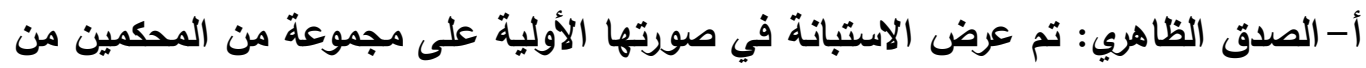

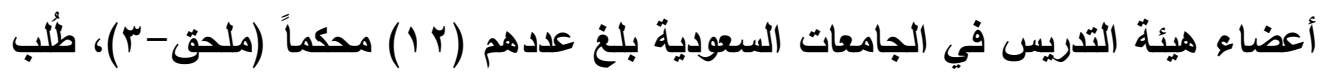

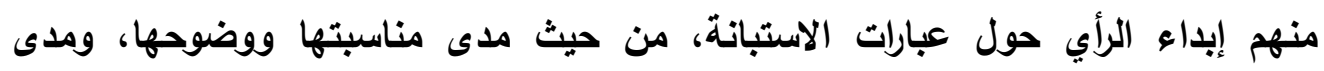

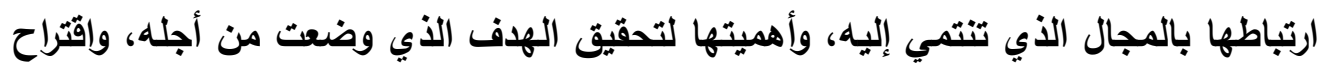
طرق تحسينها وقد بينت نتائج هذا الإجراء توفر مؤثر الصدق الظاهري للاستبانة.. ب- صدق الاتساق الاخلي: قام الباحث بحساب صدق المقياس باستخذام بيانات التطبيق

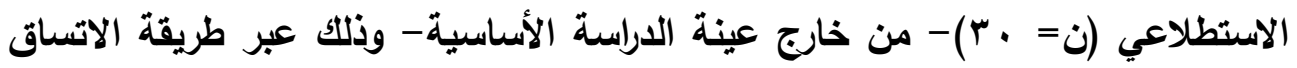
الداخلي؛ والتي تعتمد على حساب معامل الارتباط البسيط لبيرسون وفق المراحل الثلاث

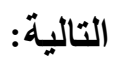

1/ب- حساب معاملات الارتباط المتبادلة بين كل فقرة من فقرات المقياس والدرجة الكلية

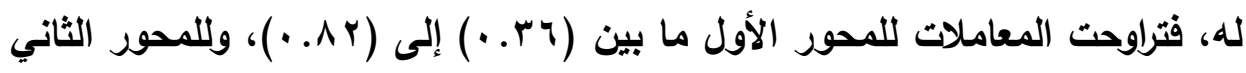

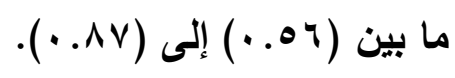


r/ب- حساب معاملات الارتباط المتبادلة بين كل فقرة من فقرات المقياس، والدرجة الكلية

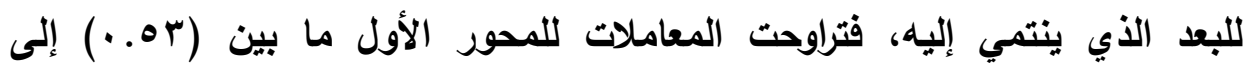

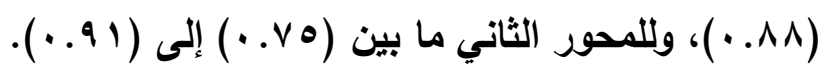

ץ/ب- حساب مصفوفة معاملات الارتباط بين الارجة الكلية لكل بعد من أبعاد المحورين

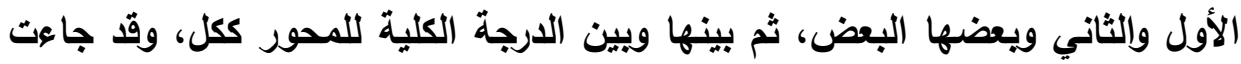

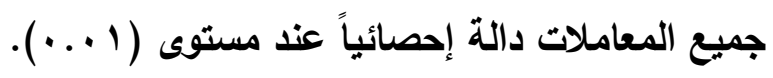

(ץ) الثبات: تم التحقق من ثبات المقياس باستخدام معادلة كرونباخ - ألفا، حيث تراوحت

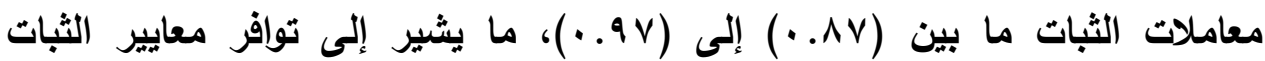
للاستبانة، ويدفع نحو الثقة في استخدامها عبر الدراسة الحالية.

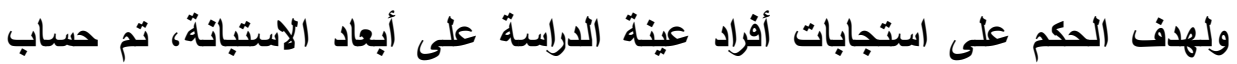
الوزن النسبي لبائل الاستجابة على فقرات الاستبانة على النحو الآتي: - طول الفئة = المدى/ عدد الفئات. - الددى= الفرق بين أكبر وأصغر بديل (درجة بديل الاستجابة) / عدد بدائل الاستجابة.

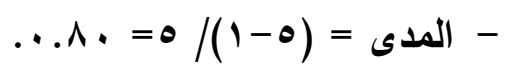

ويالتالي يكون مقياس الحكم على درجة التوفر على النحو الآتي:

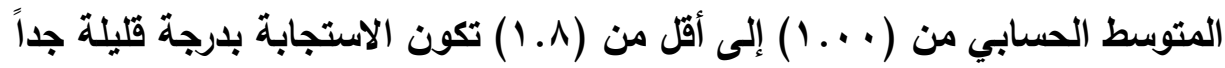

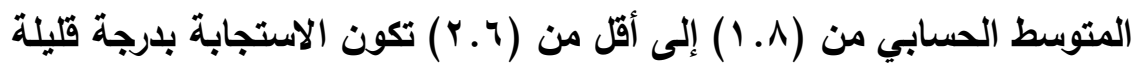

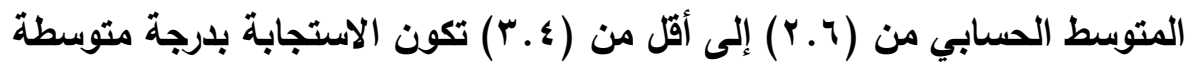

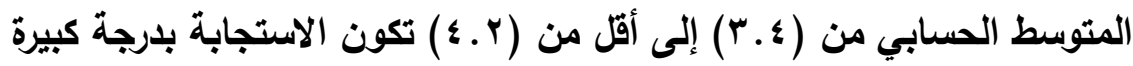

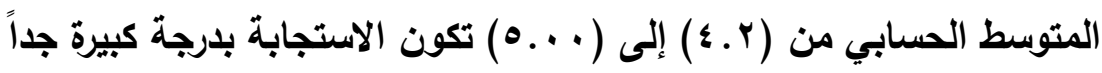

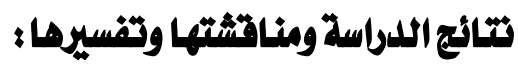

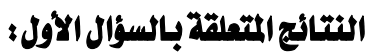

والذي ينص على "ما درجة استخام قادة المدارس بمحافظة العقيق للإدارة الإكترونية من وجهة نظر القادة والمعلمين"؟ وللإجابة عن هذا السؤال، تم حساب المتوسطات الحسابية

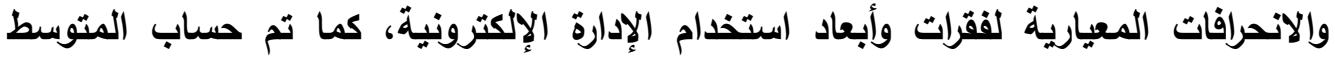
الحسابي العام والانحراف المعياري العام، والجدول (1) يوضح أهم هذه النتائج. 
جدول (1) المتوسطات الحسابية والانحرافات المعيارية لاستجابات أفراد عينة الدراسة على أبعاد المحور

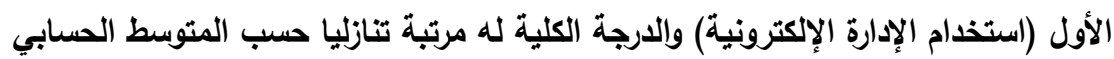

\begin{tabular}{|c|c|c|c|c|}
\hline درجة الاستخدام & الانحراف المعياري & المتوسط الحسابي & 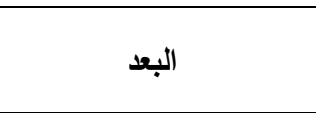 & رقم البعد في \\
\hline كبيرة & 1.07 & 3.53 & شؤون الطلاب & $r$ \\
\hline متوسطة & 1.14 & $\mathbf{3 . 3 7}$ & شؤون الموظفين & $r$ \\
\hline متوسطة & 1.15 & 3.01 & الثؤون المدرسية & 1 \\
\hline متوسطة & 1.12 & 3.31 & \multicolumn{2}{|c|}{ لارجة الكلية لاستخذام الإدارة لإكترونية } \\
\hline
\end{tabular}

تبين النتائج في الجدول (1) أن الارجة الكلية لتقدير أفراد عينة الدراسة لاستخدام الإدئه

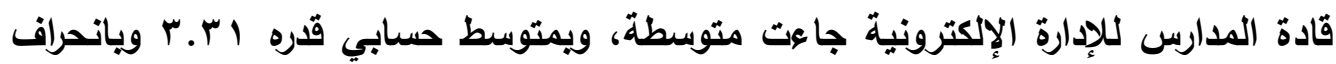
معياري بلغ r.1.1، ويرى الباحث أن تطبيق قادة المدارس بمحافظة العقيق للإدارة الإكترونية جاء بلرجة متوسطة الأمر الذي لا يلبي احتياجات المستفيدين بلرجة كبيرة، رغم

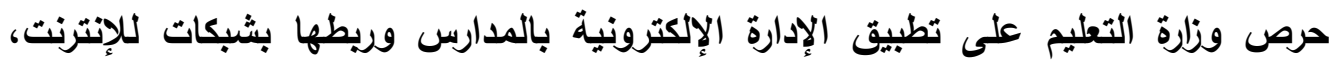
وإيجاد برامج إلكترونية مدعومة من قبل الوزارة، وتوفير أجهزة، ودورات تدريبية للعاملين. كما تبين النتائج أن بعد الشؤون المدرسية جاء بلرجة متوسطة، وهو ما يمكن عزوه

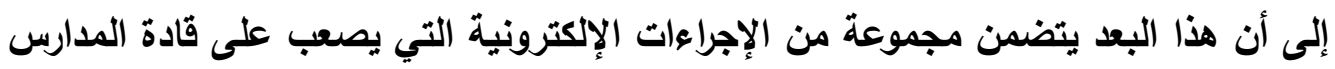

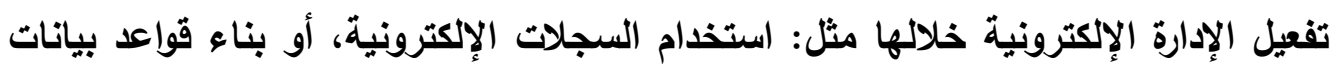
لكافة محتويات العمل الإداري بالمدرسية. كذلك تبين النتائج أن بعد شؤون الموظفين جاء بلرجة متوسطة، وهو ما يمكن عزوه إلى أن هذا البعد يتضمن مجموعة من الإجراءات الإلكترونية والبرامج المعدة من قبل الوزارة مما يسهل العمل على تلك البرامج في: تحويل الملف الخاص بكل موظف إلى جهة مهلة الإنلة الجديدة في حال نقله إلكترونياً، أو إعداد قاعدة بيانات تشمل بيانات لكافة العاملين بالمدرسة. فيما تبين النتائج أن بعد شؤون الطلاب جاء بلرجة كبيرة، وهو ما يمكن عزوه إلى

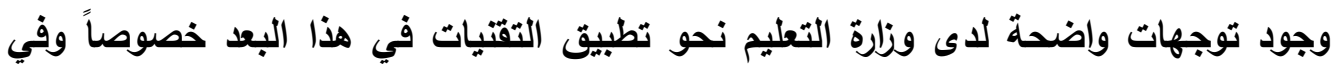

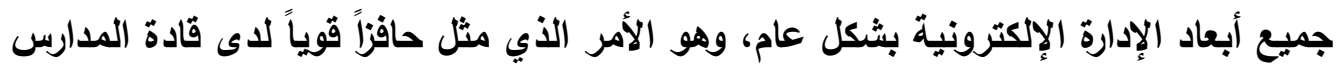
نحو تفعيل التكنولوجيا في إدارة الشؤون الخاصة بالطلاب. 


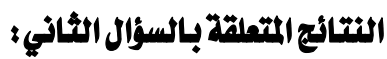

والذي ينص على: "هل توجد فروق ذات دلالة إحصائية عند مستوى الدلالة 0.05 كالة

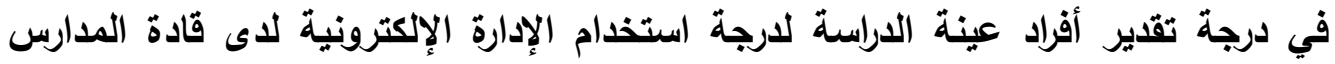
بمحافظة العقيق تعزى إلى متغيرات الدراسة (طبيعة العمل، سنوات الخبرة، المرحلة التعليمية، المؤهل العلمي، التخصص)"؟ وللإجابة عن هذا السؤال، تم إجراء ما يلي. أولاً: متغير طبيعة العمل. تم إجراء اختبار ت (T-test) لتحديد ما إذا كان هناك فروق ذات دلالة إحصائية بين متوسطي عينتين مستقلتين، نظراً لتوزيع عينة الدراسة وفقاً لهذا المتغير إلى مجموعتين. جدول (Y) نتائج اختبار ت (T-test) للتعرف على الفروق بين استجابات عينة الاراسة على المحور الأول (استخدام الإدارة الإكترونية) وفقاً لمتغير طبيعة العمل

\begin{tabular}{|c|c|c|c|c|c|c|c|c|}
\hline الإحصائية & قيمة & الحرية & الانحراف & الحستوسط & العدد & المجموعات & البعد & م \\
\hline .07 & \multirow{2}{*}{. .01} & \multirow{2}{*}{$r \leq \Lambda$} & 6.99 & 34.03 & MTI & المعلمون & \multirow{2}{*}{ المدرسية } & \multirow{2}{*}{1} \\
\hline غير دالة & & & 8.90 & 33.04 & rq & القادة & & \\
\hline זr. & \multirow{2}{*}{$1 . r}$. & \multirow{2}{*}{$r \leq \Lambda$} & 5.66 & 31.83 & TrI & المعلمون & \multirow{2}{*}{ شؤونَ } & \multirow{2}{*}{$r$} \\
\hline غير دالة & & & 7.31 & 30.14 & rq & القادة & & \\
\hline \multirow{2}{*}{ غير دالة آل } & \multirow{2}{*}{1.07} & \multirow{2}{*}{$r \leq \Lambda$} & 6.78 & 44.76 & TrI & المعلمون & \multirow{2}{*}{ شؤون } & \multirow{2}{*}{$r$} \\
\hline & & & 8.96 & 42.07 & rq & القادة & & \\
\hline \multirow{2}{*}{ غير دالة } & \multirow{2}{*}{1.41} & \multirow{2}{*}{$r \leq \Lambda$} & 16.95 & 110.62 & TrI & المعلمون & \multirow{2}{*}{\multicolumn{2}{|c|}{ للدحرجة الكلية }} \\
\hline & & & 23.04 & 105.25 & rq & القادة & & \\
\hline
\end{tabular}

يتبين من الجدول (Y) عدم وجود فروق ذات دلالة إحصائية عند مستوى الدلالة بين المعلمين وقادة المدارس في الارجة الكلية وأبعاد المحور الأول (استخدام الإدارة الإكترونية) حيث لم تصل قيمة (ت) حد الدلالة الإحصائية، ويعزو الباحث النتيجة الحالية إلى طبيعة استخدام التقتيات في الإدارة، والتي تتميز بأن لها نتائج مشاهدة كتقليل الوقت المستغرق في أداء المهمة أو على مستوى جودة المهمة، وهو ما يجعل عملية التقييم ميسرة، ولذا لم لمان يختلف المعلمون في تقييمهم لاستخدام القادة للإدارة الإلكترونية مع تقييم القادة لأدائهم 


\section{ثانياً : متفير سنوات الخبرة.}

تم إجراء اختبار تحليل التباين الأحادي One-Way Anova لتحديد ما إذا كان هناك فروقاً ذات دلالة إحصائية في استجابات عينة الداسة وفقاً لمتثير (سنوات الخبرة)، والجدول(ץ) يبين نتائج هذا الإجراء. جدول (ץ) نتائج تحليل التباين الأحادي للفروق بين متوسطات استجابات عينة الاراسة على المحور الأول (استخدام الإدارة الإلكترونية) طبقاً لمتغير سنوات الخبرة الخبرة

\begin{tabular}{|c|c|c|c|c|c|c|}
\hline الإحصائية & قفيمة & متربعات & الدرية & مجموع مريعات & مصدر التباين & المحاور \\
\hline \multirow{3}{*}{ غير دالة 0.12} & \multirow{3}{*}{2.12} & 158.69 & 2 & 317.38 & بين المجموعات & \multirow{3}{*}{ الدرسية } \\
\hline & & \multirow{2}{*}{74.94} & 247 & 18509.54 & داخل المجموعات & \\
\hline & & & 249 & 18826.92 & المجموع & \\
\hline \multirow{3}{*}{0.18} & \multirow{3}{*}{1.73} & 87.82 & 2 & 175.63 & بين المجموعات & \multirow{3}{*}{ الموظفين } \\
\hline & & \multirow{2}{*}{50.84} & 247 & 12557.81 & داخل الهجموعات & \\
\hline & & & 249 & 12733.44 & المجموع & \\
\hline \multirow{3}{*}{ غير دالة 0.07} & \multirow{3}{*}{2.78} & 210.24 & 2 & 420.47 & بين المجموعات & \multirow{3}{*}{ شُؤون الطلاب } \\
\hline & & \multirow{2}{*}{75.77} & 247 & 18714.66 & داخل المجموعات & \\
\hline & & & 249 & 19135.14 & المجموع & \\
\hline \multirow{3}{*}{ غير دالة 0.09} & \multirow{3}{*}{2.46} & 1226.21 & 2 & 2452.42 & بين المجموعات & \\
\hline & & \multirow{2}{*}{498.32} & 247 & 123085.48 & داخل المجموعات & \multirow{2}{*}{ المحور الأول } \\
\hline & & & 249 & 125537.90 & المجموع & \\
\hline
\end{tabular}

تظهر نتائج الجدول (r) عدم وجود فروق ذات دلالة إحصائية في استجابات أفراد

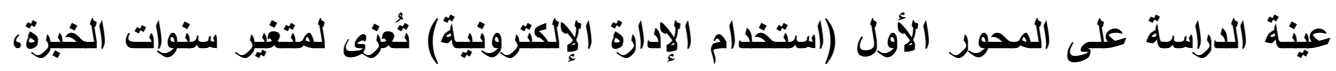

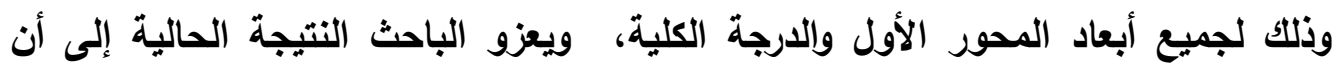
مفهوم الإدارة الإكترونية من الدفاهيم الحيثة في الميدان التريوي، وأن تطبيقه ما زال يحتاج

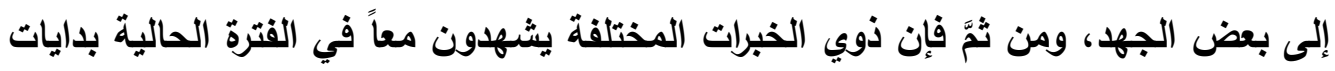

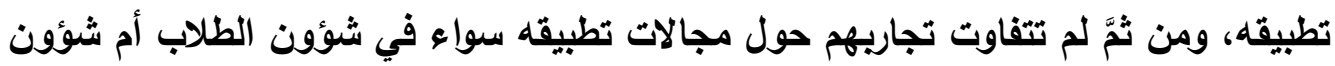
الموظفين أم الثؤون المدرسية، ويالتالي في الدرجة الكلية بالثكل الكبير. 
ثالثاً: متفير المرحلة التعليمية. تم إجراء اختبار تحليل التباين الأحادي لتحديد ما إذا كان هناك فروقاً ذات التهات دلالة

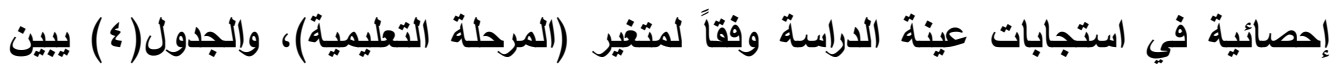
ذلك. جدول ( ؛) نتائج تحليل أحادي الاتجاه للفروق بين متوسطات استجابات عينة الدراسة على المحور

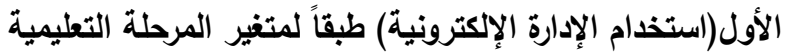

\begin{tabular}{|c|c|c|c|c|c|c|}
\hline الإحصائية & قيمة & المربعات & الدرية & مجموع مربعات & مصدر التباين & البعد \\
\hline \multirow{3}{*}{0.05} & \multirow{3}{*}{3.04} & 226.31 & 2 & 452.62 & بين المجموعات & \multirow{3}{*}{ الثدؤونة } \\
\hline & & \multirow{2}{*}{74.39} & 247 & 18374.30 & داخل المجموعات & \\
\hline & & & 249 & 18826.92 & المجموع & \\
\hline \multirow{3}{*}{0.05} & \multirow{3}{*}{4.01} & 200.12 & 2 & 400.24 & بين المجموعات & \multirow{3}{*}{ شؤونين } \\
\hline & & \multirow{2}{*}{49.93} & 247 & 12333.21 & داخل المجموعات & \\
\hline & & & 249 & 12733.44 & المجموع & \\
\hline \multirow{3}{*}{$\begin{array}{c}0.07 \\
\text { غير دالة }\end{array}$} & \multirow{3}{*}{1.73} & 132.44 & 2 & 264.88 & بين المجموعات & \multirow{3}{*}{ شؤون } \\
\hline & & \multirow{2}{*}{76.40} & 247 & 18870.26 & داخل المجموعات & \\
\hline & & & 249 & 19135.14 & المجموع & \\
\hline \multirow{3}{*}{0.05} & \multirow{3}{*}{3.29} & 1629.66 & 2 & 3259.31 & بين المجموعات & \multirow{3}{*}{ اللارجة الكلية } \\
\hline & & 495.06 & 247 & 122278.59 & داخل المجموعات & \\
\hline & & & 249 & 125537.90 & المجموع & \\
\hline
\end{tabular}

تظهر نتائج الجدول (ع) وجود فروق ذات دلالة إحصائية في استجابات أفراد عينة

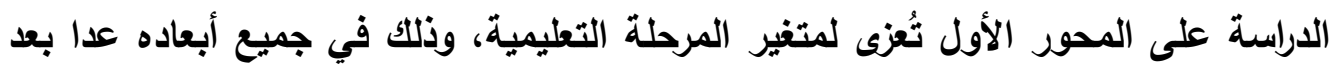
شؤون الطلاب فلم تكن الفروق فيه ذات دلالة إحصائية. وقد تم استخدام اختبار شيفيه Scheffe Test جدول (ه) نتائج اختبار Scheffe Test لالالة الفروق وفقاً لمتغير المرحلة التعليمية

\begin{tabular}{|c|c|c|c|c|c|}
\hline (دال لصالح) & مستوى & الفرق بين متوسطين & المجموعة (ب) & المجموعة (أ) & البعد \\
\hline الثانوية & $\ldots 1$ & $* Y . \wedge \wedge$ & الابتدائية & \multirow{2}{*}{ الثانوية } & \multirow{2}{*}{ الثؤون الدرسية } \\
\hline الثانوية & $\ldots 1$ & $* \varepsilon . Y q$ & المتوسطة & & \\
\hline الثانوية & $\ldots .1$ & *Y.qT & الابتدائية & \multirow{2}{*}{ الثانوية } & \multirow{2}{*}{ شؤون الموظفين } \\
\hline الثانوية & $\ldots$ & *T.AV & المتوسطة & & \\
\hline
\end{tabular}


درجة استخدام الإدارة الإلكترونية وعلاقتها بالإبداع الإداري لدى قادة المدارس بمحافظة العقيق

\begin{tabular}{|c|c|c|c|c|c|}
\hline الثانوية & $\ldots 1$ & *A.६1 & الابتـائية & \multirow{2}{*}{ الثانوية } & \multirow{2}{*}{ للدحور الأول } \\
\hline الثانوية & $\ldots 1$ & $* 11 \ldots$ & المتوسطة & & \\
\hline
\end{tabular}

يتبين من الجدول (•) أن اتجاه دلالة الفروق لصالح المرحلة الثانوية، أي عينة الدارسة ترى بصورة دالة إحصائياً أن استخدام الإدارة الإكترونية في المرحلة الثانوية يستم بصورة أوضح لاى قادة تلك المرحلة عن غيرها من مراحل التعليم العام، ويعزو الباحث النتيجة الحالية في دلالتها على وجود فروق في استجابات عينة الدارة في استخدام قادة

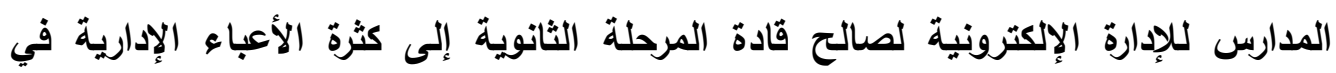

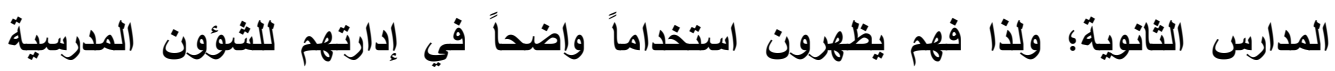
وشؤون الموظفين واللارجة الكلية للمجال بصورة أكبر مما يظهره غيرهم من قادة المراحل التعليمية الأخرى، فجاءت الفروق دالة إحصائياً لصالحهم.

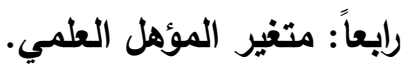
تم استخدام اختبار ت (T-test) لتحديد ما إذا كان هناك فروقاً ذات دلالة إحصائية بين متوسطات استجابات أفراد عينة الدارسة على المحور الأول طبقاً لمتغير المؤهل العلمي.

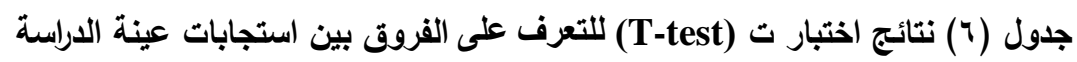

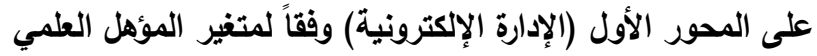

\begin{tabular}{|c|c|c|c|c|c|c|c|}
\hline الإحصائية & قيمة & درجة الحرية & الانحراف & المتوبط الحسابي & العدد & المجموعات & البعد \\
\hline \multirow{2}{*}{ غير دالة } & \multirow{2}{*}{.011} & \multirow{2}{*}{$r \leq \Lambda$} & 8.54 & 33.18 & Y19 & بكالوريوس & الشؤون \\
\hline & & & 9.86 & 33.00 & r & ماجستير فأعلى & المدرسية \\
\hline \multirow{2}{*}{ غير دالة 999} & \multirow{2}{*}{$\cdots r$} & \multirow{2}{*}{$r \leqslant \Lambda$} & 6.94 & 30.33 & 119 & بكالوريوس & 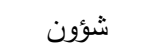 \\
\hline & & & 8.61 & 30.35 & r & ماجستير فأعلى & الموظفين \\
\hline \multirow{2}{*}{ غير دالة 7} & \multirow{2}{*}{1.91} & \multirow{2}{*}{$r \leq \Lambda$} & 8.47 & 42.78 & Y19 & بكالوريوس & 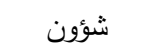 \\
\hline & & & 10.33 & 39.58 & ו & ماجستير فأعلى & الطلاب \\
\hline \multirow{2}{*}{ غير دالة عـ . . } & \multirow{2}{*}{$1 . \vee \wedge$} & \multirow{2}{*}{$r \leq \Lambda$} & 21.74 & 106.29 & 419 & بكالوريوس & الدرجة الكلية \\
\hline & & & 27.22 & 102.94 & ऍ & ماجستير فأعلى & للمحور الأول \\
\hline
\end{tabular}

تثير النتائج في الجدول (†) إلى عدم وجود فروق ذات دلالة إحصائية تعزى لمتغير

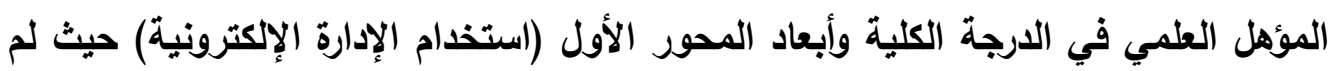
تصل قيمة (ت) حد الدلالة الإحصائية. ويعزو الباحث ذلك إلى ما سبق الإثارة إليه من الإل الإل

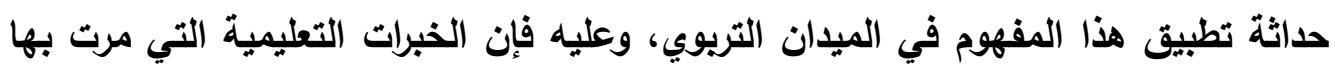


عينة الاراسة من خلال دراستهم سواء في البكالوريوس أو في الدراسات العليا لم تتناول هذا

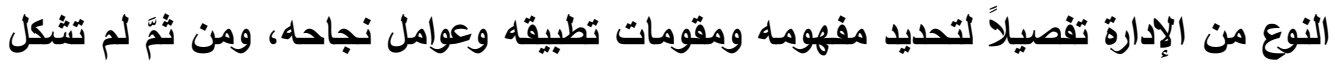
وعياً حقيقاً حوله إذ لو تم تناوله في المقررات المختلفة فإنها يتم تناوله عرضاً وليس تفصيلاً.

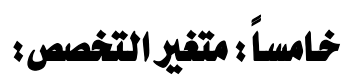

تم استخدام اختبار ت (T-test) لتحديد دلالة الفروق طبقاً لمتغير التخصص والمحدد في تخصصين (علوم طبيعية، علوم انسانية).

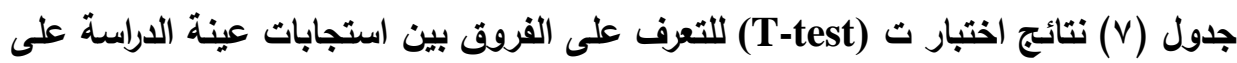

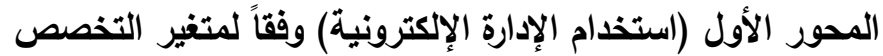

\begin{tabular}{|c|c|c|c|c|c|c|c|}
\hline الإحصائية & قيمة & درجة & الانحراف & المتوبط الحسابي & العدد العد & التخصص & البعد \\
\hline \multirow{2}{*}{ غير دالة الة } & \multirow{2}{*}{.$r \Lambda$} & \multirow{2}{*}{$r \leq \Lambda$} & 9.14 & 33.37 & $|r|$ & علوم طبيعية & \multirow{2}{*}{ الشؤون المدرسية } \\
\hline & & & 8.29 & 32.95 & 149 & علوم إنسانية & \\
\hline \multirow{2}{*}{ غير دالة } & \multirow{2}{*}{.10} & \multirow{2}{*}{$r \leq \Lambda$} & 7.29 & 30.83 & $|r|$ & علوم طبيعية & \multirow{2}{*}{ شؤون الموظفين } \\
\hline & & & 7.01 & 29.86 & 149 & علوم إنسانية & \\
\hline \multirow{2}{*}{ غير دالة • • • } & \multirow{2}{*}{$.9 r$} & \multirow{2}{*}{$r \leq \Lambda$} & 8.77 & 43.43 & $|r|$ & علوم طبيعية & \multirow{2}{*}{ شؤون الطلاب } \\
\hline & & & 8.68 & 41.40 & 149 & علوم إنسانية & \\
\hline \multirow{2}{*}{ غير دالة } & \multirow{2}{*}{1.7} & \multirow{2}{*}{$r \leqslant \wedge$} & 23.11 & 107.64 & $|r|$ & علوم طبيعية & الدرجة الكلية \\
\hline & & & 21.78 & 104.22 & 149 & علوم إنسانية & للمحور الأول \\
\hline
\end{tabular}

يتبين من الجدول (V) عدم وجود فروق ذات دلالة إحصائية تعزى لمتغير التخصص في التئي الارجة الكلية وأبعاد المحور الأول (استخدام الإدارة الإكترونية) حيث لم تصل قيمة (ت) حد

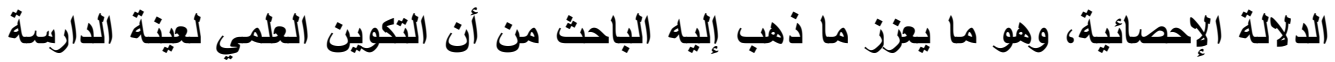
من المعلمين وقادة المدارس لم يتضمن في مقرراته مقررات تتضمن الإدارة الإكترونية

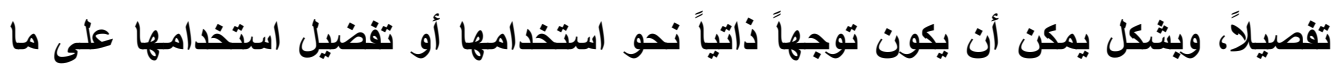

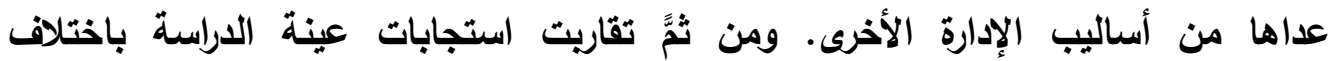
تخصصاتها الأدبية والعلمية حول المحور الأول للاستبانة (الأبعاد والارجة الكلية) بالثكل

الأي لم يكثف عن وجود فروق حقيقية بينها. 


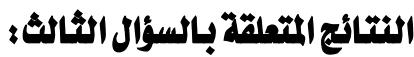

الذي ينص على :"ما درجة الإبداع الإداري لاى قادة العدارس بمحافظة العقيق من وجهة نظر قادة ومعلمي المدارس؟"، وللإجابة عن هذا السؤال تم حساب المتوسطات الحسابية والانحرافات المعيارية لأبعاد الإبداع الإداري.

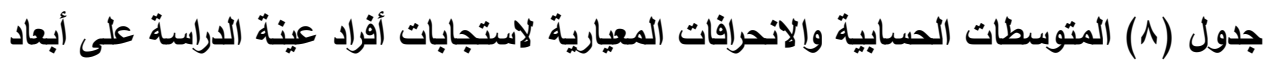

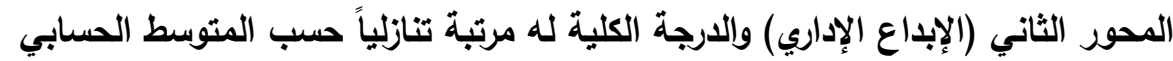

\begin{tabular}{|c|c|c|c|c|}
\hline درجة الإبداع الإداري & المعباري & الحسابي & البعد & رقم البعد في \\
\hline كبيرة & 0.98 & 3.80 & المحافظة على الاتجاه ومواصلته & - \\
\hline كبيرة & 0.98 & 3.73 & 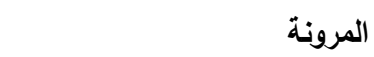 & r \\
\hline كبيرة & 1.00 & 3.68 & الطلاقة & 1 \\
\hline كبيرة & 1.04 & 3.52 & الأصالة & $r$ \\
\hline متوسطة & 1.07 & 3.36 & الحساسية للمشكلات & $\varepsilon$ \\
\hline كبيرة & 1.01 & 3.62 & \multicolumn{2}{|c|}{ الدرجة الكلية للإبداع الإداري } \\
\hline
\end{tabular}

تبين النتائج في الجدول (^) أن الارجة الكلية لتقدير أفراد عينة الاراسة للإبداع الإداري

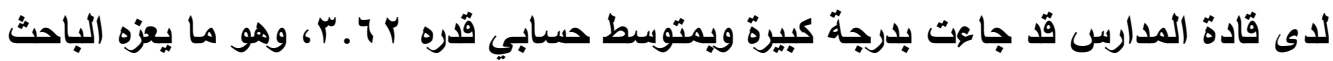

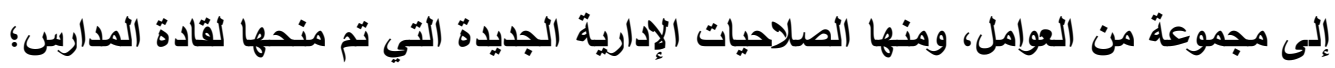
والتي جعلتهم يمارسون مهامهم الإدارية بدرجة عالية من الإبداع حسبما أظهرت النتيجة الحالية. إضافة إلى أن قادة المدارس يحاولون بصورة أو بأخرى إظهار مدارسهم بصورة الإداعة

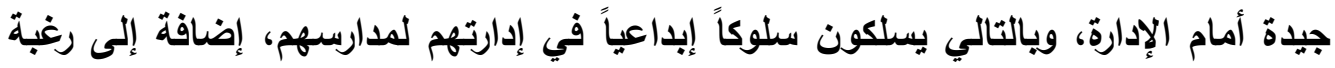

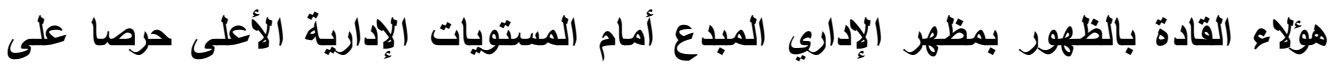

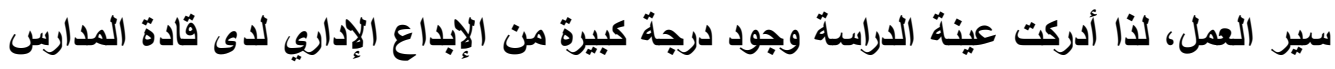
بمحافظة العقيق. - مئ. كما تبين النتائج أن تقدير عينة الدراسة للإبداع الإداري لاى قادة الددارس من خلال

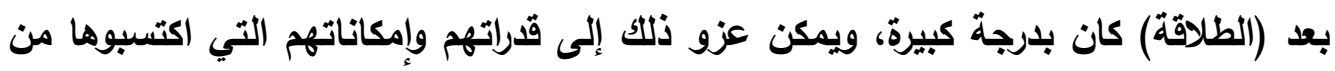

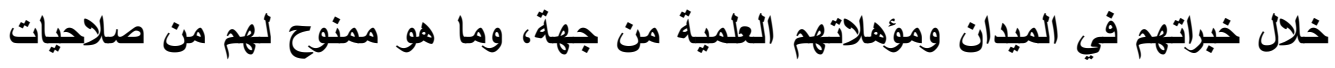
من جهة أخرى، وهما الأمرين الذين دعما ممارسات قادة المدارس الدالة على الطلاقة، 
كقرتهم على اقتراح حلول سريعة لمشكلات العمل، وطرح أفكار غير تقليدية لتطوير العمل والوصول به إلى مستويات متقدمة. كما أن التعامل مع مختلف فئات المجتمع من أولياء

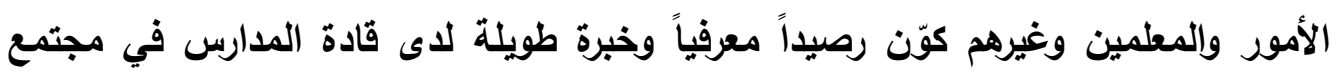

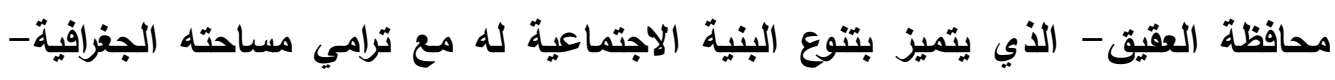

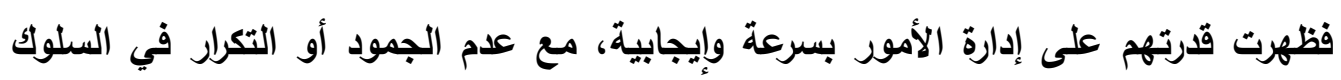
الإداري.

كذلك تبين النتائج أن تقدير عينة الدراسة للإبداع الإداري لدة قادة المدارس من خلال

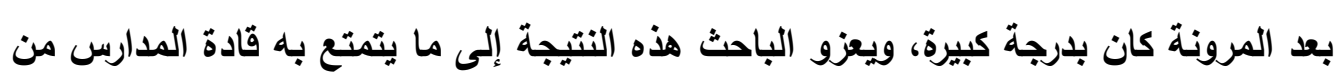

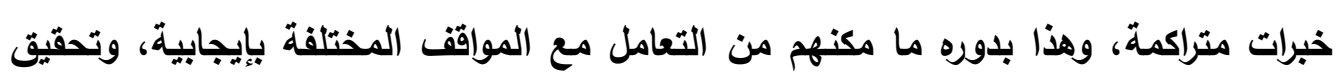

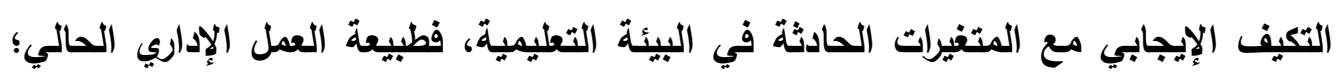
والذي أتاح لقادة المدارس صلاحيات واسعة، وكذلك طبيعة التغيرات التربوية في العملية التعليمية والتي جعلت المتعلم هو محور العملية التعليمية.

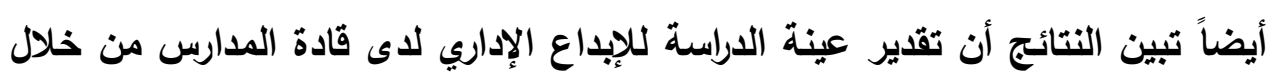

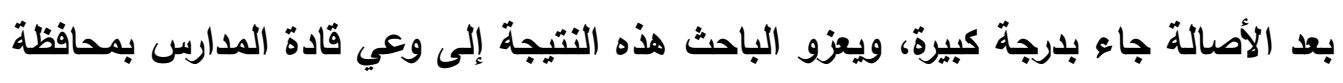

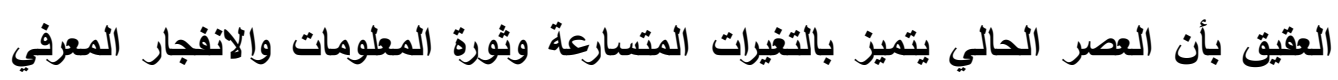

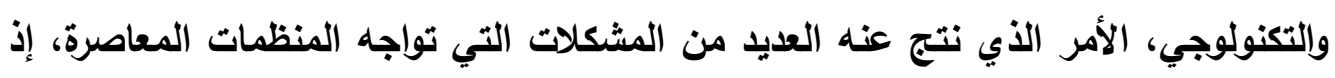

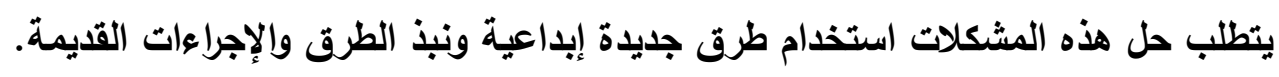

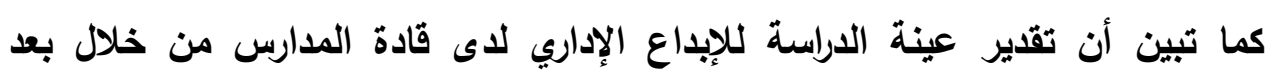

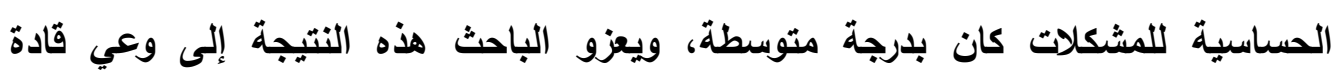

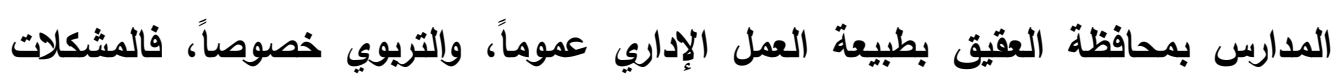

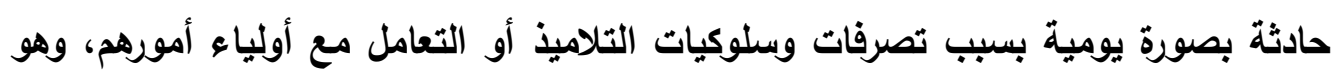

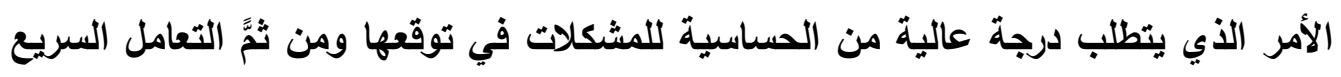

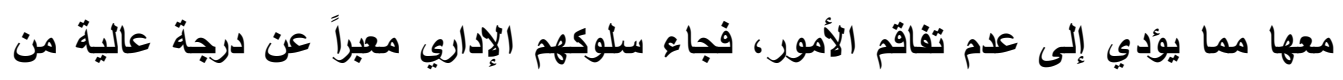

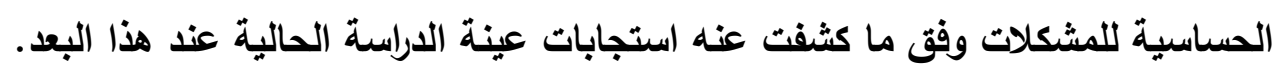

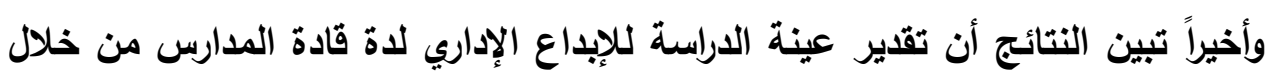

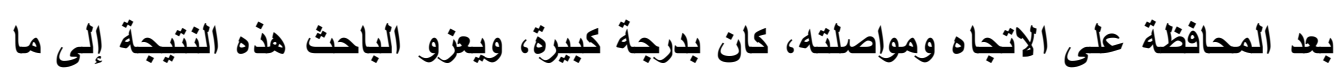


يتمتع به قادة المدارس في محافظة العقيق من خبرات ومؤهلات علمية اكسبتهم الثقة بأنفهر، وجعلتهم يتحلون بالنزاهة في التعامل الإداري على المستوى الشخصي والاجتماعي. النتائج المتعلقة بالسؤال الرابع ومناقشتها وتفسيرها:

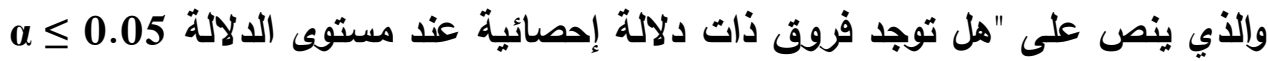
في تقدير أفراد عينة الدراسة لارجة الإبداع الإداري لاى قادة المدارس في محافظة العقيق

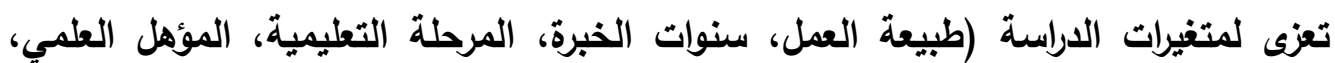

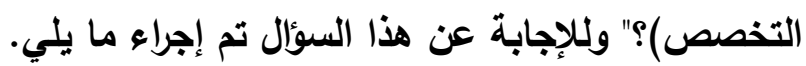
أولاً: متغير طبيعة العمل:

تم استخدام اختبار ت (T-test) لالالة الفروق بين متوسطي عينتين مستقلتين، نظراً لتوزيع عينة الدراسة وفقاً لهذا المتغير إلى مجموعتين هما: القادة، والمعلمين. جلول (9) نتائج اختبار ت (T-test) للتعرف على الفروق بين استجابات عينة الدراسة على المحور الثاني

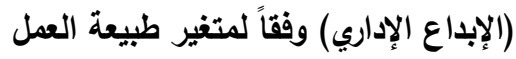

\begin{tabular}{|c|c|c|c|c|c|c|c|c|}
\hline الإحصائية & قيمة & الحرية & الانحراف & الحسابي & العدد & المجموعات & البعد & م \\
\hline \multirow{2}{*}{ غير دالة . غ } & \multirow{2}{*}{$\cdot . \wedge \vee$} & \multirow{2}{*}{$r \leq \Lambda$} & 3.05 & 19.07 & YrI & المعلمون & \multirow{2}{*}{ الطلاقة } & \multirow{2}{*}{1} \\
\hline & & & 4.49 & 18.32 & rq & القادة & & \\
\hline \multirow{2}{*}{$\ldots 0$} & \multirow{2}{*}{ r.IV } & \multirow{2}{*}{$r \leqslant \Lambda$} & 2.72 & 20.24 & YYI & المعلمون & \multirow{2}{*}{ المرونة } & \multirow{2}{*}{ r } \\
\hline & & & 4.36 & 18.44 & rq & القادة & & \\
\hline \multirow{2}{*}{$\cdots 1$} & \multirow{2}{*}{ Y.71 } & \multirow{2}{*}{$r \leqslant \Lambda$} & 3.31 & 19.66 & RTI & المعلمون & \multirow{2}{*}{ الأصالة } & \multirow{2}{*}{$r$} \\
\hline & & & 4.70 & 17.30 & rq & القادة & & \\
\hline \multirow{2}{*}{$\ldots 0$} & \multirow{2}{*}{ r. \&. } & \multirow{2}{*}{$r \leq \Lambda$} & 2.59 & 18.76 & rMI & المعلمون & \multirow{2}{*}{ لل للمشكلات } & \multirow{2}{*}{$\varepsilon$} \\
\hline & & & 4.82 & 16.57 & rq & القادة & & \\
\hline \multirow{2}{*}{ غير دالة 9} & \multirow[b]{2}{*}{1.71} & \multirow[b]{2}{*}{$r \leqslant \Lambda$} & 2.64 & 20.21 & RTI & المعلمون & \multirow{2}{*}{ المحافظة على الاتجاه } & \multirow[b]{2}{*}{ 。 } \\
\hline & & & 4.35 & 18.81 & rq & القادة & & \\
\hline \multirow{2}{*}{$\ldots 0$} & \multirow{2}{*}{ r.19 } & \multirow{2}{*}{$r \leqslant \Lambda$} & 12.07 & 97.93 & YM & المعلمون & \multirow{2}{*}{\multicolumn{2}{|c|}{ الارجة الكلية للمحور }} \\
\hline & & & 20.63 & 89.45 & rq & القادة & & \\
\hline
\end{tabular}

يتبين من الجدول (9) وجود فروق ذات دلالة إحصائية بين المعلمين وقادة المدارس في الارجة الكلية وثثلاثة أبعاد من أبعاد المحور الثاني (الإبداع الإداري) وهي: المرونة، 
والأصالة، الحساسية للمشكلات؛ بينما تبين عدم وجود فروق ذات دلالة إحصائية في باقي

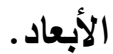

ويعزو الباحث النتيجة الحالية في دلالتها على وجود فروق في الدرجة الكلية للإبداع الإداري لاى قادة المدارس من وجهة نظرهم مقارنة بتقييم المعلمين لهم إلى رغبة قادة المدارس بالعقيق في إظهار أنفسهم كمستحقين للقيادة، وأنهم جديرون بها. ثانياً: متغير سنوات الخبرة. تم استخدام اختبار تحليل التباين الأحادي (One-Way Anova) للتأكد من صدق هذه الفروق بين فئات متغير سنوات الخبرة، والجدول ( • 1) يبين نتائج هذا الإجراء. جدول (• (1) نتائج تحليل أحادي الاتجاه للفروق بين متوسطات استجابات عينة الدراسة على المحور الثاني(الإبداع الإداري) طبقاً لمتغير سنوات الخبرة

\begin{tabular}{|c|c|c|c|c|c|c|}
\hline الإحصائية & قيمة & المتوسطات & الحرية & مجموع مربعات & مصدر التباين & المحاور \\
\hline \multirow{3}{*}{$\begin{array}{c}0.71 \\
\text { غير دالة }\end{array}$} & \multirow{3}{*}{0.35} & 6.57 & 2 & 13.14 & بين المجموعات & \multirow{3}{*}{ الطلاقة } \\
\hline & & \multirow[t]{2}{*}{19.01} & 247 & 4695.24 & داخل المجموعات & \\
\hline & & & 249 & 4708.38 & المجموع & \\
\hline \multirow{3}{*}{$\begin{array}{c}0.76 \\
\text { غير دالة }\end{array}$} & \multirow{3}{*}{0.27} & 4.87 & 2 & 9.75 & بين المجموعات & \multirow{3}{*}{ المرونة } \\
\hline & & \multirow{2}{*}{18.05} & 247 & 4458.98 & داخل المجموعات & \\
\hline & & & 249 & 4468.72 & المجموع & \\
\hline \multirow{3}{*}{$\begin{array}{c}0.42 \\
\text { غير دالة }\end{array}$} & \multirow{3}{*}{0.86} & 18.45 & 2 & 36.90 & بين المجموعات & \multirow{3}{*}{ الأصالة } \\
\hline & & \multirow{2}{*}{21.37} & 247 & 5278.16 & داخل المجموعات & \\
\hline & & & 249 & 5315.06 & المجموع & \\
\hline \multirow{3}{*}{$\begin{array}{c}0.13 \\
\text { غير دالة }\end{array}$} & \multirow{3}{*}{2.09} & 45.10 & 2 & 90.20 & بين المجموعات & \multirow{3}{*}{ للمشكلات } \\
\hline & & \multirow{2}{*}{21.61} & 247 & 5338.06 & داخل المجموعات & \\
\hline & & & 249 & 5428.26 & المجموع & \\
\hline \multirow{3}{*}{$\begin{array}{c}0.70 \\
\text { غير دالة }\end{array}$} & \multirow{3}{*}{0.36} & 6.33 & 2 & 12.66 & بين المجموعات & \multirow{3}{*}{ الاتجاه ومواصلتهة على } \\
\hline & & \multirow{2}{*}{17.76} & 247 & 4387.19 & داخل المجموعات & \\
\hline & & & 249 & 4399.86 & المجموع & \\
\hline \multirow{3}{*}{$\begin{array}{c}0.48 \\
\text { غير دالة }\end{array}$} & \multirow{3}{*}{0.73} & 293.72 & 2 & 587.43 & بين المجموعات & \multirow{3}{*}{ للاححور الثاني الكلية } \\
\hline & & \multirow{2}{*}{400.52} & 247 & 98928.04 & داخل المجموعات & \\
\hline & & & 249 & 99515.48 & المجموع & \\
\hline
\end{tabular}


تظهر نتائج الجدول (· (1) عدم وجود فروق ذات دلالة إحصائية في استجابات أفراد

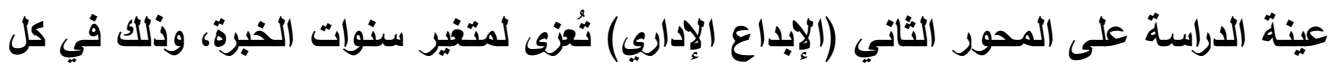

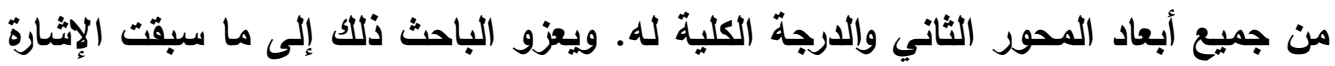
إليه من عوامل ارتفاع الإبداع الإداري لاى عينة الدراسة بصورة كلية، ومن ذلك منحهم صلاحيات واسعة مكنتهم من ممارسة العمل الإداري بمدارس بإبداع، ولكون هذه الصلاحيات الإنهات

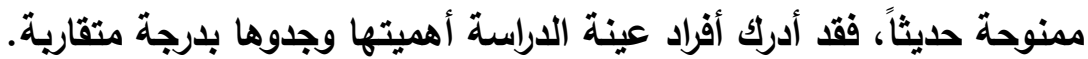
ثالثاً: متغير المرطلة التعليمية. وللتأكد من صدق هذه الفروق تم استخدام اختبار تحليل التباين الأحاد لكثف دلالة الفروق بين أكثر من متوسطين، ويبين الجدول رقم (11) نتائج هذا الاختبار.

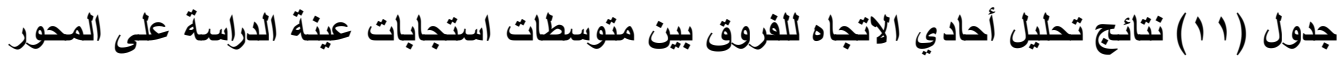

الثاني (الإبداع الإداري) وفقاً لمتغير المرحلة التطيمية التئية

\begin{tabular}{|c|c|c|c|c|c|c|}
\hline الإحصائية & قيمة & متوسط المربعات & الحرية & مريعات & مصدر التباين & البعد \\
\hline \multirow{3}{*}{$\begin{array}{c}0.51 \\
\text { غير دالة }\end{array}$} & \multirow{3}{*}{0.67} & 12.73 & 2 & 25.45 & بين المجموعات & \multirow{3}{*}{ الطلاقة } \\
\hline & & \multirow{2}{*}{18.96} & 247 & 4682.93 & داخل المجموعات & \\
\hline & & & 249 & 4708.38 & المجموع & \\
\hline \multirow{3}{*}{$\begin{array}{c}0.40 \\
\text { غير دالة }\end{array}$} & \multirow{3}{*}{0.91} & 16.32 & 2 & 32.63 & بين المجموعات & \multirow{3}{*}{ المرونة } \\
\hline & & \multirow{2}{*}{17.96} & 247 & 4436.09 & داخل المجموعات & \\
\hline & & & 249 & 4468.72 & المجموع & \\
\hline \multirow{3}{*}{$\begin{array}{c}0.79 \\
\text { غير دالة }\end{array}$} & \multirow{3}{*}{0.23} & 5.01 & 2 & 10.01 & بين المجموعات & \multirow{3}{*}{ الأصالة } \\
\hline & & \multirow{2}{*}{21.48} & 247 & 5305.05 & داخل المجموعات & \\
\hline & & & 249 & 5315.06 & المجموع & \\
\hline \multirow{3}{*}{$\begin{array}{c}0.93 \\
\text { غير دالة }\end{array}$} & \multirow{3}{*}{0.08} & 1.70 & 2 & 3.40 & بين المجموعات & \multirow{3}{*}{ للمشكلات } \\
\hline & & \multirow{2}{*}{21.96} & 247 & 5424.86 & داخل المجموعات & \\
\hline & & & 249 & 5428.26 & المجموع & \\
\hline \multirow{3}{*}{$\begin{array}{c}0.91 \\
\text { غير دالة }\end{array}$} & \multirow{3}{*}{0.10} & 1.75 & 2 & 3.49 & بين المجموعات & المحافظة على \\
\hline & & \multirow{2}{*}{17.80} & 247 & 4396.37 & داخل المجموعات & الاتجاه \\
\hline & & & 249 & 4399.86 & المجموع & ومواصلته \\
\hline \multirow{2}{*}{$\begin{array}{c}0.86 \\
\text { غير دالة }\end{array}$} & \multirow{2}{*}{0.16} & 62.53 & 2 & 125.05 & بين المجموعات & \multirow{2}{*}{ اللارجة الكلية } \\
\hline & & 402.39 & 247 & 99390.42 & داخل المجموعات & \\
\hline
\end{tabular}


درجة استخدام الإدارة الإلكترونية وعلاقتها بالإبداع الإداري لدى قادة المدارس بمحافظة العقيق

\begin{tabular}{|c|c|c|c|c|c|c|}
\hline الإحصائية & قيمة & المربعات & الحرية & مربعوع مجوت & مصدر التباين & البعد \\
\hline & & & 249 & 99515.48 & المجموع & \\
\hline
\end{tabular}

تظهر نتائج الجدول (11) عدم وجود فروق ذات دلالة إحصائية في استجابات أفراد

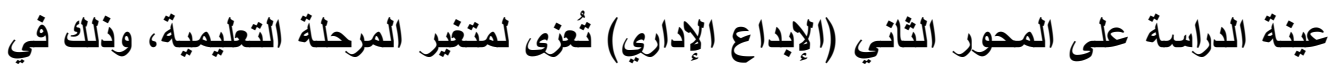

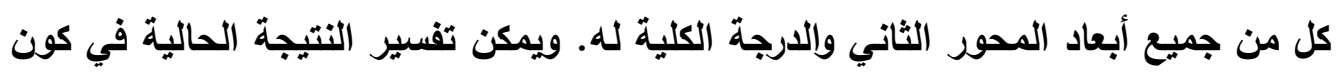
المتغيرات التي تستدعي الإبداع الإداري من متغيرات اجتماعية ومؤهلات وقدرات لادى قادة المدارس، تبدو واحدة أو متقارية في مدارس التعليم العام بمحافظة العقيق، ولذا يمارس الإدئ

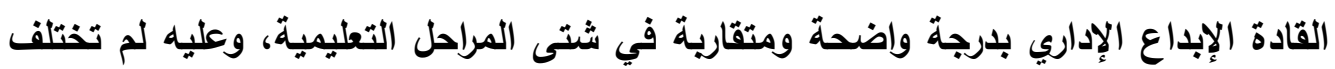
استجابات عينة الاراسة في تقييم هذا المتغير وفقاً لاختلاف المرحلة التي يعملون بها. رابعاً: متغير المؤهل العلمي.

تم استخدام اختبار ت (T-test) لتحديد ما إذا كان هناك فروقاً ذات دلالة إحصائية في الفروق بين متوسطات استجابات أفراد عينة الدراسة طبقاً لمتغير المؤهل العلمي.

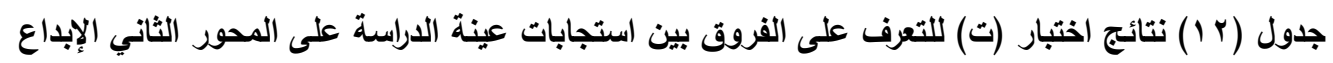
الإداري وفقاً لمتغير المؤهل العلمي

\begin{tabular}{|c|c|c|c|c|c|c|c|}
\hline الإحصائية & قيمة & الحرية & الانحراف المعياري & المتوسط الحسبي & العدد & المجموعات & البعد \\
\hline \multirow{2}{*}{ غير دالة } & \multirow{2}{*}{$\therefore 7}$. & \multirow{2}{*}{$r \leq \Lambda$} & 4.31 & 18.47 & Y19 & بكالوريوس & \multirow{2}{*}{ الطلاقة } \\
\hline & & & 4.64 & 17.97 & $r$ & ماجستير فأعلى & \\
\hline \multirow{2}{*}{ غير دالة } & \multirow{2}{*}{$\therefore .9 r$} & \multirow{2}{*}{$r \leqslant \Lambda$} & 4.18 & 18.74 & Y19 & بكالوريوس & \multirow{2}{*}{ المرونة } \\
\hline & & & 4.65 & 18.00 & M & ماجستير فأعلى & \\
\hline \multirow{2}{*}{ غير دالة } & \multirow{2}{*}{$1 . \leqslant 0$} & \multirow{2}{*}{$r \leqslant \Lambda$} & 4.55 & 17.74 & Y) & بكالوريوس & \multirow{2}{*}{ الأصالة } \\
\hline & & & 5.01 & 16.45 & r & ماجستير فأعلى & \\
\hline \multirow{2}{*}{ غير دالة 1 ـ . } & \multirow{2}{*}{$1 . \leqslant r$} & \multirow{2}{*}{$r \leqslant \Lambda$} & 4.63 & 16.98 & Y 19 & بكالوريوس & \multirow{2}{*}{ للاشكساسية } \\
\hline & & & 4.85 & 15.71 & r & ماجستير فأعلى & \\
\hline \multirow{2}{*}{ غير دالة } & \multirow{2}{*}{$\therefore \wedge r$} & \multirow{2}{*}{$r \leq \Lambda$} & 4.25 & 19.06 & Y19 & بكالوريوس & \multirow{2}{*}{ الاتحافظة على ومواصلته } \\
\hline & & & 3.84 & 18.39 & $r$ & ماجستير فأعلى & \\
\hline \multirow{2}{*}{ غير دالة } & \multirow{2}{*}{$1.1 \mathrm{~V}$} & \multirow{2}{*}{$r \leqslant \Lambda$} & 19.84 & 90.99 & rrI & بكالوريوس & \multirow{2}{*}{ للامحور الثانية الكلية } \\
\hline & & & 20.93 & 86.52 & rq & ماجستير فأعلى & \\
\hline
\end{tabular}




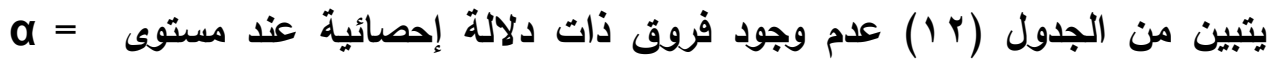
(0.05) تعزى لمتغير المؤهل العلمي في الارجة الكلية وأبعاد المحور الثاني (الإبداع الإداري) حيث لم تصل قيمة ت حد الدلالة الإحصائية. ويمكن تفسير النتيجة الحالية في ظل كون درجة الإبداع الإداري كبيرة لدى قادة المدارس؛ والتي جعلت عينة الدراسة تدركها بصرف الإدئ النظر عن المؤهل العلمي لديها، كما أن الممارسات الخاصة بتطبيق الإبداع في الإدارة تُعد

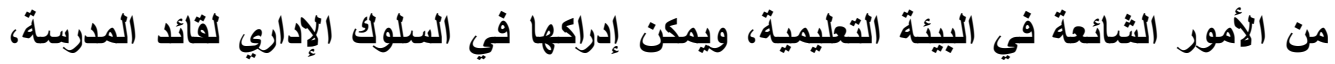
وهو الأمر الذي جعل متغير المؤهل العلمي لا يؤثز في إحداث فروق في استجابات عينة

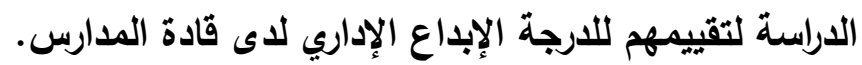
خامساً: متغير التخصص. تم استخدام اختبار ت (T-test) لتحديد ما إذا كان هناك فروقاً ذات دلالة إحصائية في الفروق بين متوسطات استجابات أفراد عينة الدراسة طبقاً لمتغير التخصص. جدول (T آ) نتائج اختبار (ت) للتعرف على الفروق بين استجابات عينة الداسة على المحور الثاني (الإبداع الإداري) وفقاً لمتغير التخصص لين التصابا

\begin{tabular}{|c|c|c|c|c|c|c|c|c|}
\hline الإحصائية & قيمة (ت) & الحرية & الانحراف & الحستوسطي & العدد & المجموعات & البعد & 5 \\
\hline \multirow{2}{*}{ غير دالة } & \multirow{2}{*}{$\cdots \leqslant \wedge$} & \multirow{2}{*}{$r \leqslant 1$} & 4.32 & 18.27 & $|r|$ & علوم طبيعية & \multirow{2}{*}{ الطلاقة } & \multirow{2}{*}{1} \\
\hline & & & 4.39 & 18.53 & 149 & علوم إنسانية & & \\
\hline \multirow{2}{*}{ غير دالة } & \multirow{2}{*}{$1 . . v$} & \multirow{2}{*}{$r \leqslant \Lambda$} & 4.12 & 18.36 & $|r|$ & علوم طبيعية & \multirow{2}{*}{ المرونة } & \multirow{2}{*}{ r } \\
\hline & & & 4.34 & 18.93 & $1 \times 9$ & علوم إنسانية & & \\
\hline \multirow{2}{*}{ 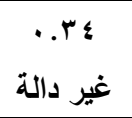 } & \multirow{2}{*}{.90} & \multirow{2}{*}{$r \leqslant \Lambda$} & 4.63 & 17.29 & $|r|$ & علوم طبيعية & \multirow{2}{*}{ الأصالة } & \multirow{2}{*}{$r$} \\
\hline & & & 4.61 & 17.85 & 149 & علوم إنسانية & & \\
\hline \multirow{2}{*}{ غير دالة } & \multirow{2}{*}{$\cdot . \leqslant 1$} & \multirow{2}{*}{$r \leqslant \Lambda$} & 4.78 & 16.95 & $1 r 1$ & علوم طبيعية & \multirow{2}{*}{ للمشكلات } & \multirow{2}{*}{$\varepsilon$} \\
\hline & & & 4.57 & 16.71 & $1 r 9$ & علوم إنسانية & & \\
\hline \multirow{2}{*}{ غير دالة } & \multirow{2}{*}{$\ldots r$} & \multirow{2}{*}{$r \leqslant \Lambda$} & 4.06 & 18.98 & $|r|$ & علوم طبيعية & \multirow{2}{*}{ الاتجاه ومواصلته } & \multirow{2}{*}{ 。 } \\
\hline & & & 4.35 & 18.97 & $1 \times 9$ & علوم إنسانية & & \\
\hline \multirow{2}{*}{ غير دالة } & \multirow{2}{*}{$\cdots \leqslant 0$} & \multirow{2}{*}{$r \leqslant \Lambda$} & 19.85 & 89.85 & $|r|$ & علوم طبيعية & \multirow{2}{*}{\multicolumn{2}{|c|}{ الارجة الكلية للمحور }} \\
\hline & & & 20.19 & 90.98 & $1 \times 9$ & علوم إنسانية & & \\
\hline
\end{tabular}

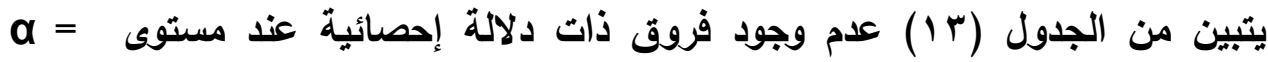
(0.05) تعزى لمتغير التخصص في الدرجة الكلية وأبعاد المحور الثاني (الإبداع الإداري) 
حيث لم تصل قيمة (ت) حد الدلالة الإحصائية. ويرى الباحث أنه يمكن تفسير هذه النتيجة في ضوء ما سبقت الإشارة إليه عند تناول متغير (المؤهل العلمي) من أن الإبداع يلاحظه ويدركه الفرد في الموقف التعليمي بسهولة، فالقائد الذي يفكر بشكل واحد ويتصرف بسلوك

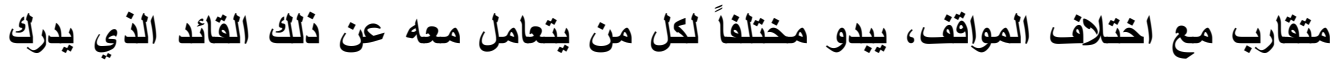
المشكلات ويتصرف معها بفاعلية، ويغير زاوية تفكيره في الأمر الواحد فضلاً عن الأمور المختلفة، ويتصرف بثقة وإيجابية، ولذا لم يؤثر متغير التخصص في توجيه استجابات عينة

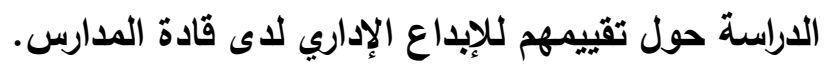

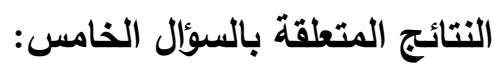
والذي ينص على: "هل هناك علاقة ارتباطية بين درجة استخدام الإدارة الإكترونية ودرجة الإبداع الإداري لاى قادة المدارس بمحافظة العقيق"؟ وللإجابة عن هذا السؤال، تم حساب معاملات ارتباط بيرسون (Person' Correlation) بين المحور الأول للاستبانة (استخدام الإدارة الإكترونية) بأبعاده الثلاثة (الثؤون المدرسية، شؤون الموظقين، شؤون الطلاب)، ويين المحور الثاني للاستبانة (الإبداع الإداري) بأبعاده الخمسة (الطلاقة، المرونة، الإنة الأصالة، الحساسية للمشكلات، المحافظة على الاتجاه ومواصلته). جلول (ه) مصفوفة معاملات الارتباط البسيط لبيرسون Person بين محوري الاستبانة ومجالاتهما الفرعية

\begin{tabular}{|c|c|c|c|c|c|}
\hline \multirow{2}{*}{ للاحدور الأول } & \multicolumn{3}{|c|}{ استخدام الإدارة الإكترونية } & \multirow{2}{*}{\multicolumn{2}{|c|}{ المحور الأول }} \\
\hline & شؤون الطلاب & شؤون الموظفين & المدرسية & & \\
\hline ***.70 & ***. . . & ***. . ๆ & ***..07 & الطلاقة & \multirow{5}{*}{$\frac{\bar{y}}{\frac{\bar{y}}{\omega}}$} \\
\hline$* * * . \diamond \wedge$ & $* * . .00$ & 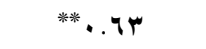 & **** ๑ $\leqslant V$ & المرونة & \\
\hline ***. . & ***. . . & ***. . & $* * .00$ & الأصالة & \\
\hline ***. & ***. $.0 \wedge$ & ***. $.0 \mathrm{~V}$ & ***. $.0 \leqslant$ & الحساسية للمشكلات & \\
\hline ***.. . & ***. . V V & ***. . V V & $* * .0$. & المحافظة على الاتجاه ومواصلته & \\
\hline$* * . .79$ & ***.70 & ***. . TV & ***. $.0 \wedge$ & لمرجة الكلية للمحور الثاني & \\
\hline
\end{tabular}

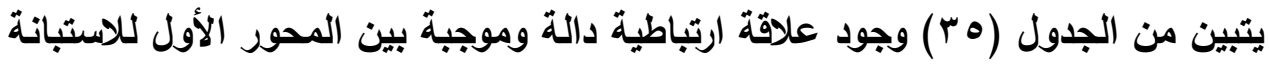

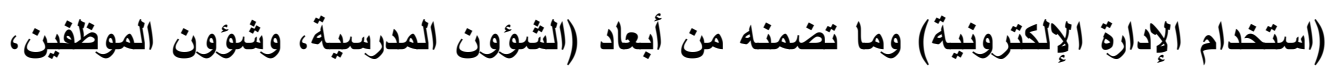


وشؤون الطلاب)، وبين المحور الثاني للاستبانة (الإبداع الإداري) وما تضمنه من أبعاد (الطلاقة، المرونة، الأصاية، الحساسية للمشكلات، المحافظة على الاتجاه ومواصلته) وكانت جميع الأبعاد دالة عند مستوى دلالة (1 (...). وكانت أقوى المعاملات بين الدرجة الكلية لاستخدام الإدارة الإكترونية ويين الارجة الكلية للإبداع الإداري حيث بلغ معامل الارتباط

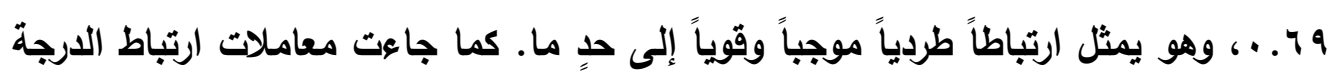

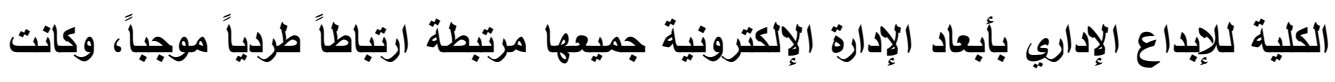

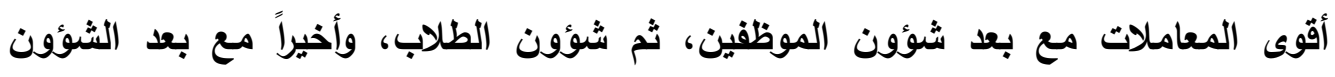

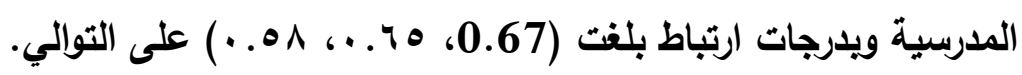
وفي ضوء النتائج السابقة تم تقديم مجموعة من التوصيات ومنها: ا. توجيه قادة المدارس إلى توظيف الإدارة الإكترونية بدرجة كبيرة في إدارة الثؤون المدرسية خاصة فيما يتعلق بتوفير قاعدة بيانات إلكترونية شاملة بمحتويات المكتبة المدرسة، وكذلك في استخدام السجلات الإكترونية لإدارة المخزون في مستودعاتها. r. إثراء مهارات قادة المدارس فيما يتعلق بتوفير محتوى تدريبي إلكتروني للموظقين،

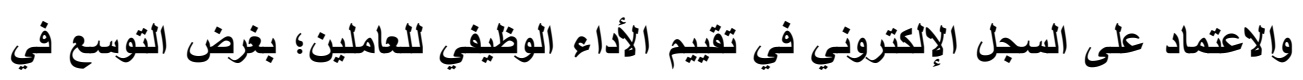

$$
\text { تطبيق الإدارة الإكترونية في المدارس. }
$$

r. تدعيم وإثراء جهود قادة المدارس الإيجابية في تطبيق الإدارة المدرسية في مجال شؤون

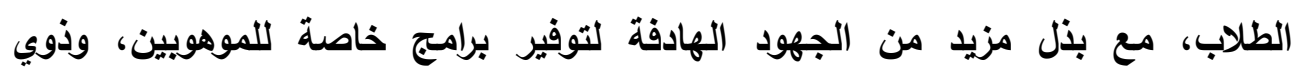
الاحتياجات الخاصة على موقع المدرسة الإلكتروني. لدري. 


\section{مراجع البعتُ}

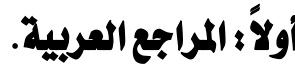

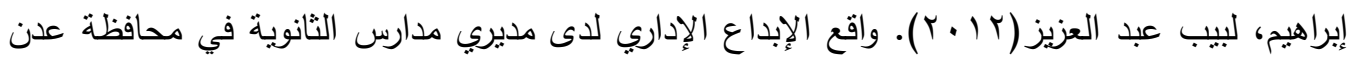

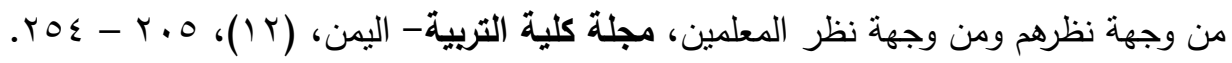

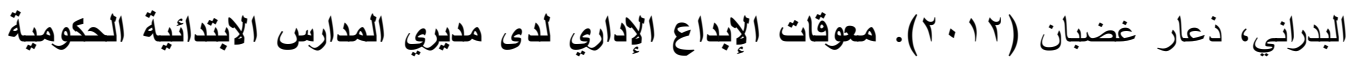

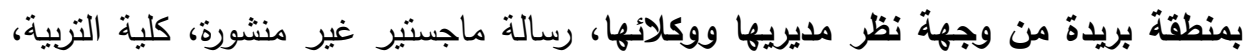

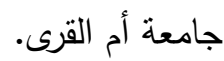
بلخي، علي فايز (ع (ب). إسهام برنامج الإدارة الإكترونية "تور" في تحسين الأداء الإداري في

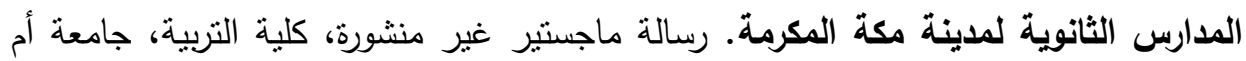
القرى.

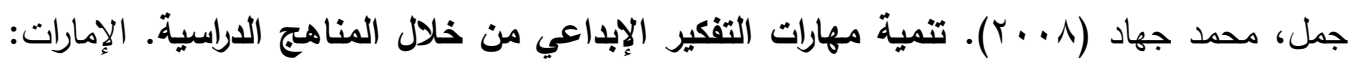

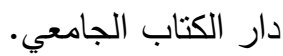

حازي، عبدالفناح بيومي (ع .ب). النظام القانوني لحماية الحكومة الإكترونية. الاسكندرية: دار

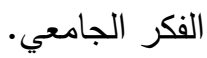

الحسن، ماجد عبد الله (1) (1). تقويم أداء الإدارة الإلكترونية في المدارس الثانوية بالملكة العربية

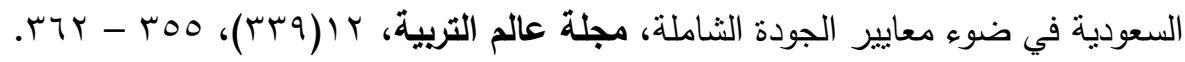

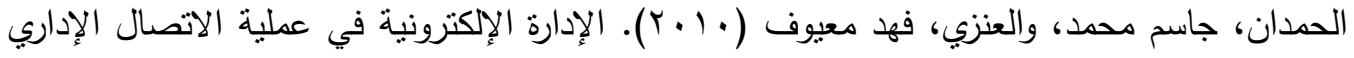

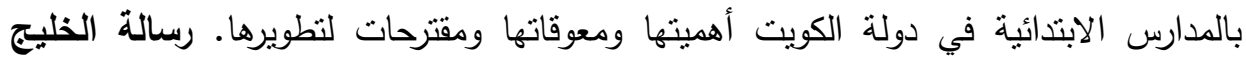

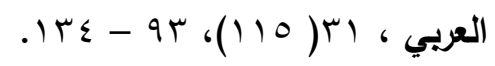

الخوالدة، محمد فلاح (10 (ب). واقع تطبيق الإدارة الإككترونية في الددارس الثانوية الخاصة في محافظة

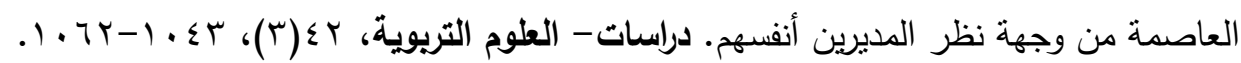

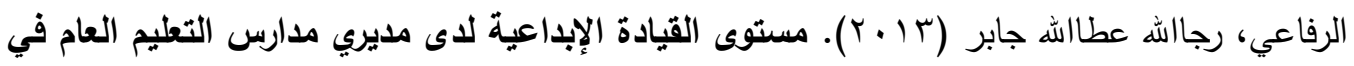
محافظة ينبع، رسالة ماجستير غير منشورة، جامعة طيية، المملكة العربية السعودية.

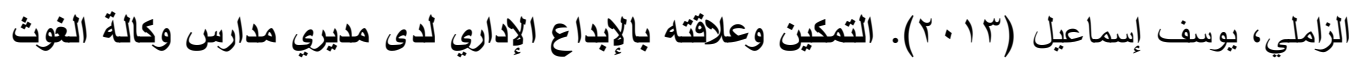

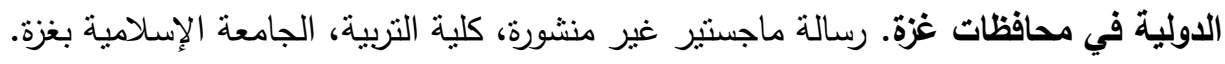

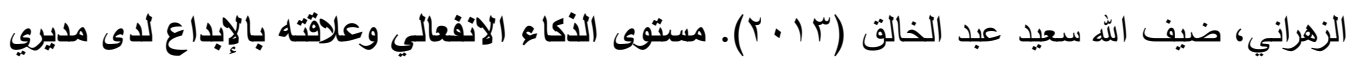
المدارس في مدينة الطائف. رسالة ماجستير غير منثورة، كلية التربية، جامعة الباحة. 
الزيود، ماجد محمد (Y ( T ). درجة ممارسة تكنولوجيا المعلومات وعلاقتها بالإبداع لدى مديري

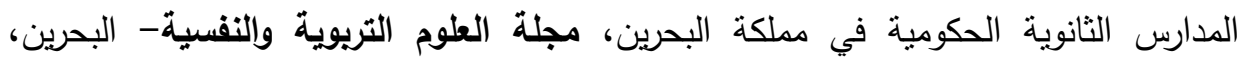

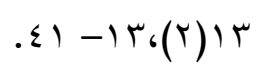

السعدية، حمدة حمد (1) (1). منطلبات تطبيق الإبداع الإداري في مدارس ولاية الرستاق بمنطقة

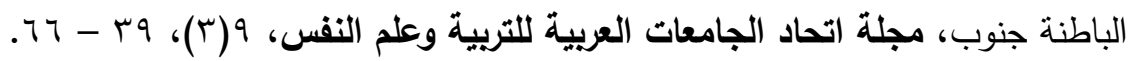
السلمي، سعيد حميد عشاي (· ( • (Y). نمط القيادة وممارسات الإبداع الإداري لمديري المدارس الثانوية

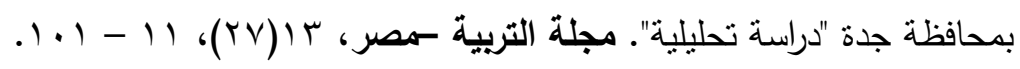

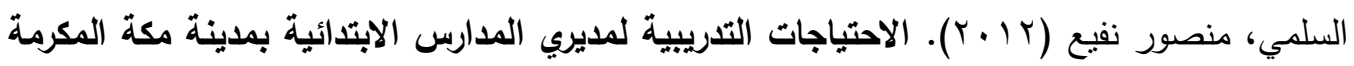

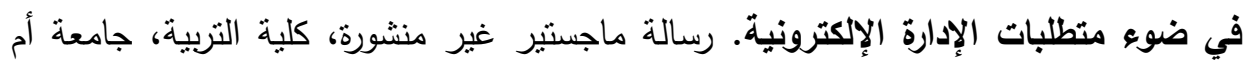
القرى.

طيب، أحمد سعد؛ والقصيمي، محمد مصطفى (r (Y). تشخيص معوقات تطبيق نماذج الإدارة

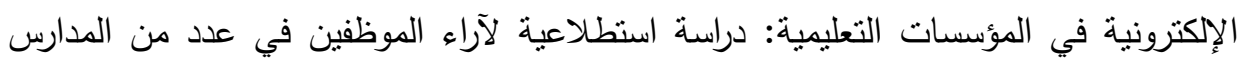

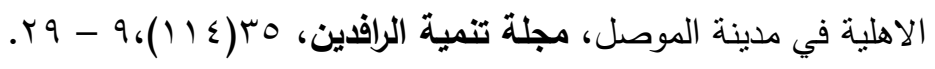

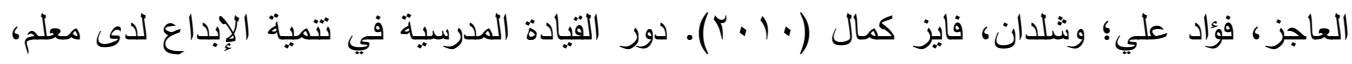
مدارس المرحلة الثانوية بمحافظات غزة من وجهة وكائ نظر المعلمين، مجلة الجامعة الإسلامية

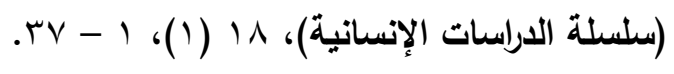

عبد الرازق، ماجدة ؛ والذبياني، منى (Y Y Y ). الإبداع الإداري مدخل لنطوير إدارة مدارس التعليم

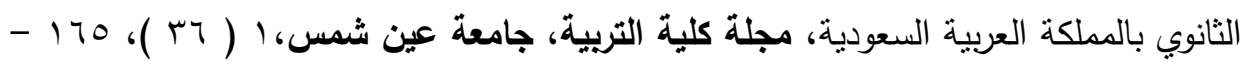

العصيمي، خالد محمد والقرني، محمد سعيد (10 • (1). دور الإدارة الإلكترونية في تطوير الإدارة

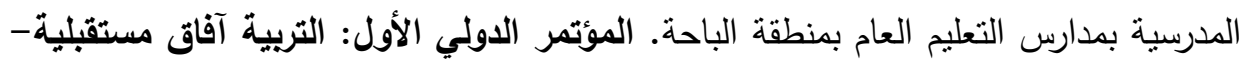

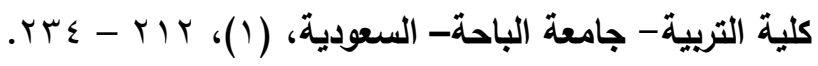
علي، لطيف محمد (1) (1). التفكير الإبداعي لدى المديرين وعلاقته بحل المشاكل الإدارية، القاهرة: (1)،

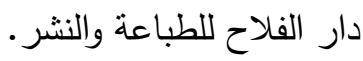

الغزاوي، تمام عبداله أحمد (10 • ب). الإبداع الإداري لمديري المدارس الحكومية في محافظة الكرك

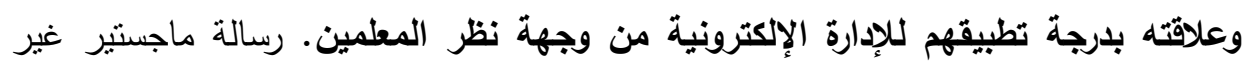

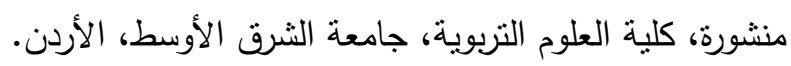


الغيث، العنود محمد (Y V V V). درجة تطبيق مديرات المدارس الحكومية لمفاهيم الإدارة الإلكترونية في

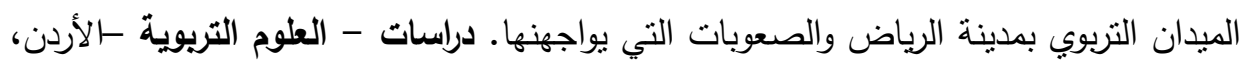

$$
\text { . } \varepsilon 1-r) ،(1) \leqslant \varepsilon
$$

فقيه، سناء عبد القادر ( . . Y). تطبيقات أساليب الإبداع الإداري في التنمية الإدارية للقيادات التريوية

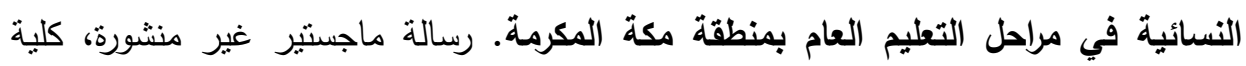

$$
\text { التربية، جامعة أم القرى. }
$$

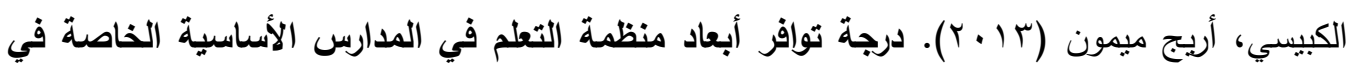

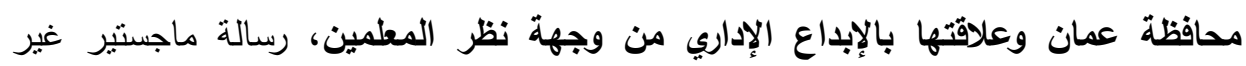

$$
\text { منشورة، الأردن، جامعة الثرق الأوسط. }
$$

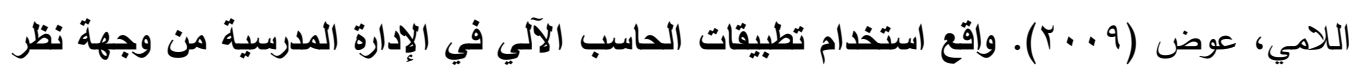

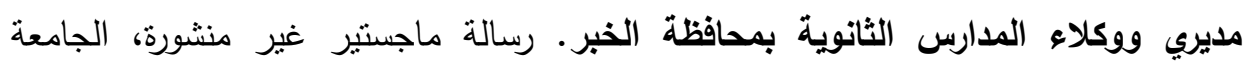
الخليجية، البحرين.

اللخاوي، محمد فتحي (^ . . r). دور مديري المدارس الإعدادية بوكالة الغوث الدولية بمحافظات غزة

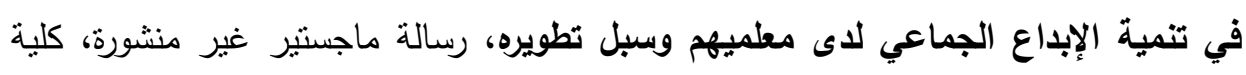
التربية، الجامعة الإسلامية، غزة.

المحامدى، ندى عبد الرحيم (0 . . ץ). الجوانب السلوكية في الإدارة المدرسية. عمان: دار الفكر للنشر

$$
\text { والتوزيع. }
$$

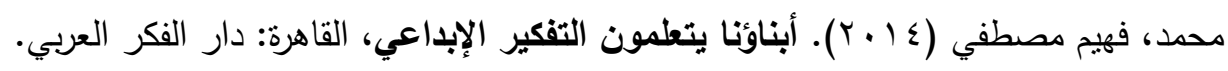

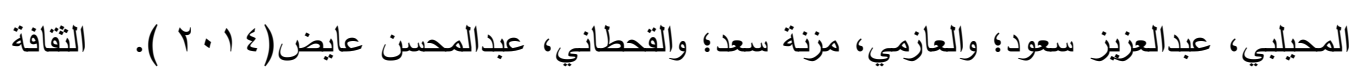

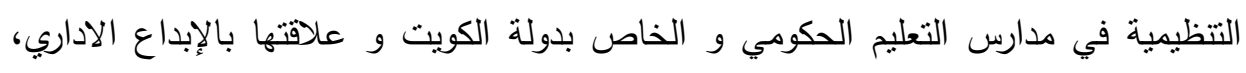

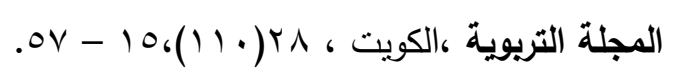

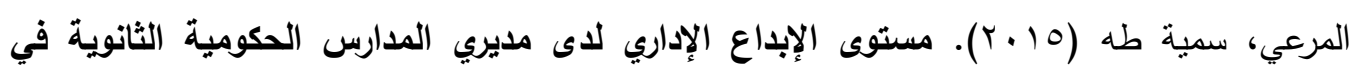

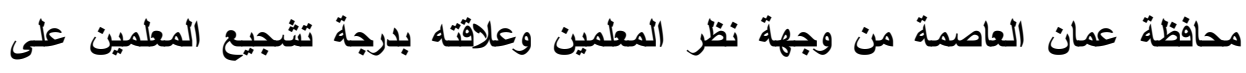

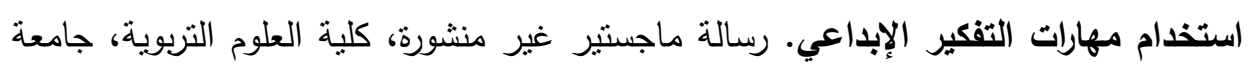

$$
\text { الثرق الأوسط. }
$$

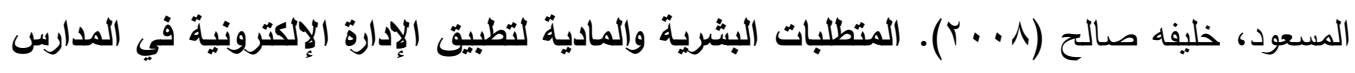

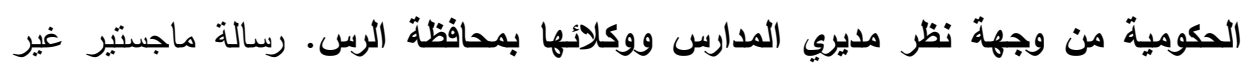

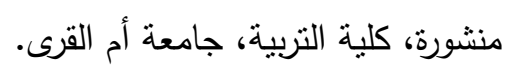




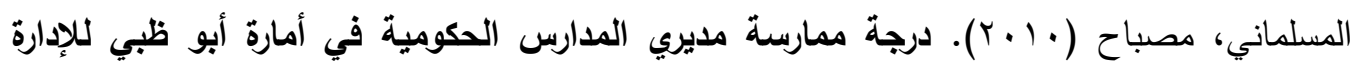
الإكترونية. رسالة ماجستير غير منشورة، جامعة عمان العربية.

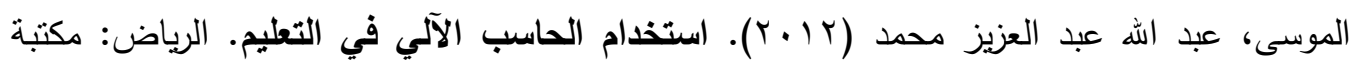
الثقيري.

\section{ثانياً: المراجع الاججنية.}

Crum K. \& Sherman H. (2008). Facilitating high achievement high school principals, reflections on their successful leadership practices. Journal of Educational Administration , 46, 562-580,

Li, G. and Ni, X. (2011). Primary EFL Teachers' Technology Use in China: Patterns and Perceptions, RELC Journal, April 1, (42), 69-85.

Russell, A. (2004) .How School Counselors Counselors Could Benefit From Management Solutions: The Case of Paperwork. U.S.A. Department of Education research and Educational Information center. Eric numbered 478218.

Salfi, N. (2011). Successful Leadership Practices of Head Teachers for School Improvement: Some Evidence from Pakistan, Journal of Educational Administration, 49( 4),414-431.

Toremen, F. (2003). Creative school and administration .Educational Sciences: Theory \& practice, 3 (1), $248-253$.

Turner L. \& Weickgenannt, A. (2009). Accounting Information Systems, Prentice, John Wiley \& Sons, INC. USA.

Yilmaz, E. (2010). The analysis of organizational creativity in schools regarding principals, ethical leadership characteristics. Journal of Social and Behavioral Sciences, 2(2), 3949-3953. 